Oxford University

Centre for

Business Taxation

\title{
Controlled Foreign Corporation Rules and Cross-Border M\&A Activity
}

\section{WP 17/17}

\author{
Dominik von Hagen \\ University of Mannheim \\ Axel Prettl \\ University of Tuebingen
}




\title{
Controlled Foreign Corporation Rules and Cross-Border M\&A Activity*
}

\author{
Dominik von Hagen $^{\mathrm{a}}$ \\ Axel Prettl ${ }^{\mathrm{b}}$
}

October 2017

\begin{abstract}
We investigate the influence of one main anti tax avoidance measure, controlled foreign corporation (CFC) rules, on cross-border merger and acquisition (M\&A) activity on a global scale. Using three different statistical methods and a large M\&A data set, we find that CFC rules distort ownership patterns due to a competitive advantage of multinational entities whose parents reside in non-CFC rule countries. First, we show that the probability of being the acquirer of a low-tax target decreases if CFC rules may be applicable to this target's income. Second, we show that CFC rules distort the acquirer's location choice of targets. Third, we show that CFC rules negatively affect the probability of being the acquirer in a cross-border M\&A. Altogether, this study shows that for affected acquirer countries, CFC rules lead to less M\&A activity in low-tax countries because profit shifting seems to be less feasible. This behavior change could result in an increase in global corporate tax revenue.
\end{abstract}

Keywords: International taxation $-\mathrm{CFC}$ rules - Profit shifting - Mergers and acquisitions - Multinational entities

JEL Classification: $\mathrm{F} 23 \cdot \mathrm{G} 34 \cdot \mathrm{H} 25 \cdot \mathrm{H} 26 \cdot \mathrm{H} 32 \cdot \mathrm{H} 73$

*The authors gratefully acknowledge the constructive comments and suggestions from Michael Devereux, James Hines, Patrick Klein, Martin Ruf, Ulrich Schreiber, Johannes Voget, seminar participants at Stanford University and workshop participants at the 2017 European Accounting Association Annual Congress as well as at the Universities of Mannheim and Tuebingen. Any errors, however, remain the responsibility of the authors.

${ }^{a}$ Dominik von Hagen, Chair of Business Administration and Taxation, Business School, University of Mannheim, 68131 Mannheim, Germany; E-mail: vonhagen@bwl.unimannheim.de

${ }^{b}$ Axel Prettl, Chair of International Business Taxation, Faculty of Economics and Social Sciences, University of Tuebingen, 72074 Tuebingen, Germany; E-mail: axel@prettl2.de 


\section{Introduction}

Globalization and its accompanying effects in various business fields such as reallocation of production or new customers all around the world are current challenges that multinational entities (MNEs) are facing globally. Further, in all these various dimensions, MNEs and countries, which are concerned about their tax revenue, compete against each other. In addition, international tax law, once a rather minor concern in corporate tax planning, has become increasingly important and MNEs try to use tax loopholes within international tax law to minimize their overall tax payments. One way to minimize tax payments can be realized by MNE-wide profit shifting, which is intensely discussed in current tax policy debates as the "Base Erosion and Profit Shifting" (BEPS) project (OECD/G20 (2015)) of the Organisation for Economic Co-operation and Development (OECD) or the anti tax avoidance directive of the European Union (EU) (European Council (2016)) show. Further, empirical literature provides extensive evidence of MNE-wide profit shifting strategies (e.g., Huizinga and Laeven (2008), Weichenrieder (2009), Grubert (2012), Dharmapala and Riedel (2013)). The basic idea of such profit shifting strategies is to reduce taxable income in high-tax countries by, e.g., royalty or interest payments from high-tax to low-tax subsidiaries. ${ }^{1}$

Several countries, however, have implemented anti tax avoidance measures to counteract this profit shifting behavior. The three major measures are transfer pricing rules, thin capitalization or interest stripping rules and controlled foreign corporation (CFC) rules. This study tries to shine some light on CFC rules, which aim at MNE-wide profit shifting strategies by immediately taxing profits of low-tax subsidiaries, redistributed or not, in the MNE's parent country if certain conditions are fulfilled. Hence, CFC rules make typical profit shifting strategies unattractive for an MNE (e.g., Altshuler and Hubbard (2003), Ruf and Weichenrieder (2012)), since these strategies do no longer reduce the MNE's tax burden.

If a company decides to engage in tax avoidance or to extend its existing tax avoidance strategies, it could try to establish a foreign subsidiary in a low-tax country as a profit shifting vehicle, where profits are taxed at a low rate. There are two common ways to establish a foreign subsidiary: greenfield investment in a new firm or buying an existing company. Our study focuses on the latter one, cross-border mergers and acquisitions (M\&As), which is considered an important form of foreign direct investment (FDI) (UNCTAD (2017)). Additionally, even more profit shifting opportunities may be given by acquiring a foreign firm, such as using existing loss carry forwards. Based on the argumentation above, one can easily imagine that the existence and strength of CFC rules that try to counteract such

\footnotetext{
${ }^{1}$ A typical profit shifting strategy looks as follows: An MNE equips a subsidiary in a low-tax country with intellectual property (IP) and equity. This subsidiary then may license IP to the parent or subsidiaries in high-tax countries that pay transfer prices (royalties) in exchange for using IP. Further, the low-tax subsidiary may provide debt to the parent or subsidiaries in high-tax countries that pay interest in exchange for the internal loan. Taken together, the royalty and interest expenses reduce taxable income in high-tax countries and increase income in low-tax countries.
} 
behavior could have an impact on cross-border M\&As and, thereby, on ownership structures of MNEs.

We investigate whether CFC rules influence ownership patterns on a global scale by analyzing the effect of CFC rules on cross-border M\&As. In our different econometrical analyses, we investigate a large data set of worldwide M\&A deals with around 14,000 observations and a hand-collected detailed CFC rule data set of 29 countries, extended by countries that do not have CFC rules, for the period 2002 to 2014. We find that CFC rules impact cross-border M\&A activity in two ways.

First, we detect that CFC rules distort the acquisition of low-tax targets. In particular, we observe that the probability of acquiring a low-tax target is negatively influenced by potential CFC rule application on the low-tax target's income. Our explanation for this finding is that MNEs with parents in non-CFC rule countries (non-CFC rule MNEs) calculate higher reservation prices for low-tax targets than MNEs with parents in CFC rule countries (CFC rule MNEs), because these targets may be used as valuable profit shifting vehicles within non-CFC rule MNEs. CFC rule MNEs, on the other side, fear the application of CFC rules on low-tax targets' income, which decreases after-tax cash flows. Hence, they calculate lower reservation prices for cross-border M\&As than non-CFC rule MNEs.

Second, we detect that CFC rules distort the direction of cross-border M\&As between firms. In particular, we observe that if a firm acquires another non-domestic firm, CFC rules negatively affect the M\&A direction, i.e., which firm becomes the acquirer and, thereby, the parent of the newly formed MNE. This finding is in line with previous research by Voget (2011), who detects that the presence of CFC rules increases the number of headquarters relocation. However, our approach differs from Voget (2011) by using a different identification strategy and analyzing M\&A observations from a different database.

Our paper contributes to tax research and policy considerations in three ways. First, we contribute to empirical tax research on the effects of CFC rules on firm behavior, where little research has been undertaken so far (see Section 2). As Egger and Wamser (2015) point out, this may be due to the difficulty of isolating the effect of anti tax avoidance measures on MNEs who operate in multiple jurisdictions and avail complex group interrelations with respect to, e.g., financing decisions. In addition, the effect of CFC rules is difficult to identify as the applicability of CFC rules depends on the foreign subsidiary's characteristics as well as its host-country's characteristics. To overcome these identification difficulties, we do not only follow a mere dummy variable approach on the presence or non-presence of CFC rules; moreover, we go into the details of each country's CFC rules by considering individual components of CFC rules.

Second, we contribute to empirical tax research in the field of M\&As and their tax-related determinants. Indeed, there are many empirical studies on the effect of taxes on M\&As from various perspectives, e.g., repatriation taxes (Voget (2011), Hanlon et al. (2015), Edwards et al. (2016), Feld et al. (2016a)), international double taxation (Huizinga and Voget (2009), 
Huizinga et al. (2012)) or capital gains taxes (Ayers et al. (2003), Ayers et al. (2007), Feld et al. (2016b), Huizinga et al. (2017)). However, besides Voget (2011), there are to our knowledge no published empirical studies that compare the effect of anti tax avoidance measures on M\&A activity over various countries. In particular, there is no such study about the increasingly important CFC rules. However, since anti tax avoidance measures are expanding as shown in Figure 1, the strand of literature dealing with location choices of MNEs and their tax-related elements becomes as important.

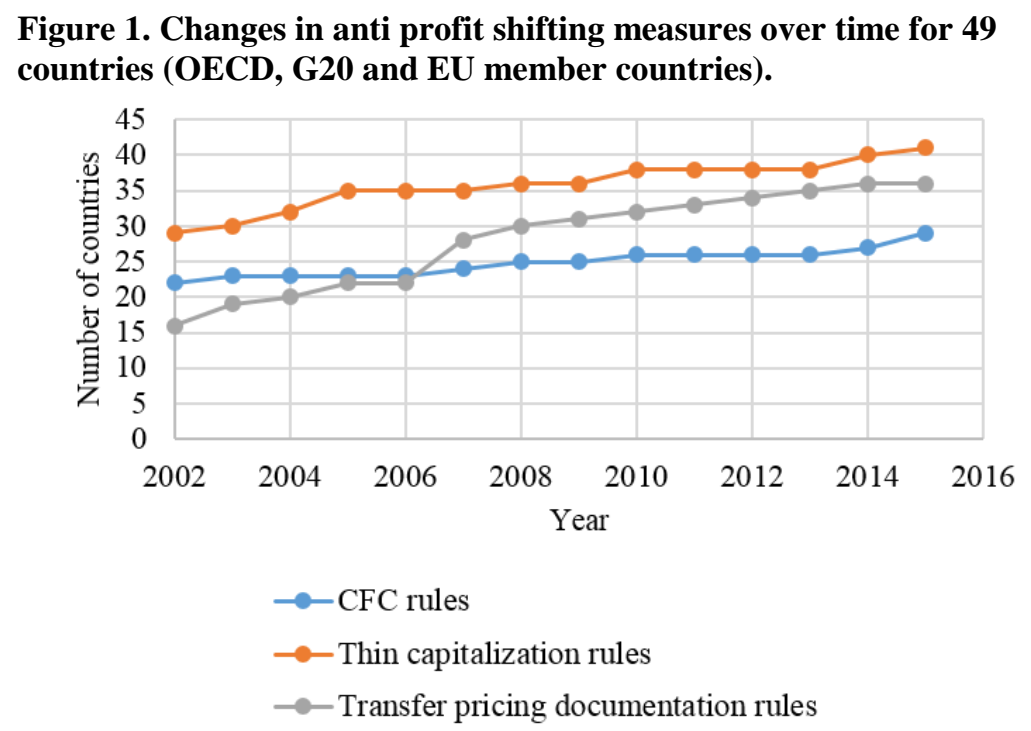

Source: Own data collection.

Third, understanding how CFC rules influence M\&A activity on a global scale is also of economic interest, as cross-border M\&As are an important form of FDI: In 2016, the value of cross-border M\&As accounted globally for 869 billion USD, which slightly exceeded the value of announced greenfield projects ( 828 billion USD, UNCTAD (2017)). Hence, our analysis on distortionary tax effects on cross-border M\&As is also of interest from a global economic and not only from countries' tax policy perspective.

The remainder of this paper proceeds as follows. Section 2 gives a brief review of empirical literature on CFC rules. Section 3 provides our analysis of the effect of CFC rules on the acquisition of low-tax targets. Section 4 analyzes the effect of CFC rules on the direction of cross-border M\&As. Finally, Section 5 sets forth our conclusions.

\section{Empirical literature on CFC rules}

CFC rules are applicable at an MNE's parent level and usually work as follows: If an MNE's foreign subsidiary fulfills certain requirements, at least a part of its income is taxed in the MNE's parent country where the CFC rule is enacted, even if no repatriation takes place. Thereby, MNE-wide profit shifting strategies become mostly ineffective. Typically, three 
requirements are crucial for CFC rule application: Low taxation of the foreign subsidiary, passive income of the subsidiary, and minimum ownership in the subsidiary. There is a high degree of variation in how CFC rules are specified, e.g., regarding what is considered low taxation or regarding a passive-to-active-income ratio that may trigger CFC rule application.

Despite the far-reaching consequences of CFC rules on MNEs' tax burdens, empirical studies on the effects of CFC rules on firm behavior are scarce. Altshuler and Hubbard (2003) find that tightening US CFC rules in 1986 has substantially reduced tax planning opportunities with financial services firms in low-tax countries; three years later, Altshuler and Grubert (2006) show that the so-called check-the-box rule, which may allow for an escape from CFC rules for US MNEs, abolished these effects. For a panel of German MNEs, Ruf and Weichenrieder (2012) detect that German CFC rules are effective in reducing passive investments in low-tax countries. These studies show that CFC rules reach the intended goal of reducing profit shifting opportunities with low-tax subsidiaries. However, Egger and Wamser (2015) find that German MNEs, whose subsidiaries are subject to CFC rules, also show significantly lower fixed assets in these subsidiaries. They conclude that CFC rules lead to an increase in cost of capital if subsidiaries are treated by CFC rules. Hence, by influencing real activity abroad, the application of CFC rules can also have non-intended "real" effects. These findings contradict the theoretical thoughts from Weichenrieder (1996) who shows that certain characteristics of CFC rules, such as an accepted passive-to active-income ratio, can lower the cost of capital in foreign subsidiaries under certain circumstances.

We aim to contribute to the scarce literature on CFC rules by investigating the effects of CFC rules on an important form of FDI-cross-border M\&A activity-that accounts for almost 1 trillion USD in 2016 (UNCTAD (2017)). In particular, in Section 3, we investigate whether CFC rules influence the acquisition of low-tax targets that potentially fall under the scope of CFC rules. In Section 4, we investigate whether CFC rules influence the direction of crossborder M\&As between firms, i.e., which firm becomes the acquirer and, thereby, the parent of the newly formed MNE.

\section{CFC rules and the acquisition of low-tax targets}

\subsection{Hypothesis development}

Non-CFC rule MNEs face fewer constraints in implementing profit shifting strategies within their group than CFC rule MNEs. ${ }^{2}$ That is because CFC rules aim at profits shifted to low-tax subsidiaries within the MNE and, thereby, make typical profit shifting strategies less

\footnotetext{
${ }^{2}$ In our analysis on the effects of CFC rules on cross-border M\&A activity, we consider CFC rules in the country of the MNE's parent to be relevant. The reason is straightforward: On the one side, a non-CFC rule MNE gets into a worse tax position if the acquisition is done via a CFC rule subsidiary; hence, the MNE would not acquire through this subsidiary. In support of this reasoning, Lewellen and Robinson (2014) find that the likelihood of choosing a subsidiary as a holding firm within an MNE is significantly lower if that subsidiary resides in a CFC rule country. On the other side, a CFC rule MNE does not get into a better tax position if the acquisition is done via a non-CFC rule subsidiary, because the parent's CFC rule would overall still be applicable in the MNE.
} 
attractive for an MNE. Following the argumentation and findings of Egger and Wamser (2015), CFC rules even increase the cost of capital of subsidiaries that fall under the scope of CFC rules. Consequently, it is less attractive for a CFC rule MNE to acquire a low-tax target that may fall under the scope of CFC rules compared to a non-CFC rule MNE. Put differently, for a non-CFC rule MNE, a low-tax target could function - in addition to other synergies - as a profit shifting vehicle within the MNE. This additional function could make a candidate target more valuable for this MNE compared to a CFC rule MNE without such profit shifting opportunities. Due to this competitive advantage, non-CFC rule MNEs may calculate higher reservation prices for foreign low-tax targets compared to CFC rule MNEs. We, therefore, hypothesize the following, stated in alternative form:

Hypothesis 1a: The probability of being the acquirer of a given low-tax target in a crossborder M\&A is higher for non-CFC rule MNEs compared to MNEs that potentially have to apply CFC rules on this target's income.

Hypothesis 1a investigates the influence of $\mathrm{CFC}$ rules on the likelihood of acquiring a given target that acquirers from various countries bid for. We also take the "opposite" perspective that a given acquirer has the choice to buy a target out of a pool of targets from various countries. Based on the reasoning above - it is less attractive for a CFC rule MNE to acquire a low-tax target that may fall under the scope of CFC rules compared to a target that does not fall under the scope of CFC rule-we hypothesize the following, stated in alternative form:

Hypothesis 1b: The probability of being the target of a given acquirer in a cross-border M\&A is lower for targets that potentially fall under the scope of CFC rules of this acquirer compared to targets that do not fall under the scope of CFC rules of this acquirer.

Almost all observed CFC rules include a so-called "minimum low tax rate threshold" requirement, which determines whether the foreign subsidiary's country is considered a lowtax country. This requirement varies over countries and time. We use these low tax rate thresholds to determine whether the target is located in a low-tax country so that CFC rules are potentially applicable. Acquirers from countries with CFC rules and a low tax rate threshold could especially aim for targets that are located in countries with a statutory corporate tax rate (STR) below their own one but above the low tax rate threshold to achieve tax rate advantages. If, however, the target is located in a country with a higher STR than the acquirer's country STR, we argue that non-CFC rule acquirers may be more prone to buy these targets. This argument is motivated by the following consideration: These acquirersother than CFC rule acquirers - could shift profits out of the high-tax target country. We, therefore, hypothesize the following, stated in alternative form:

Hypothesis 1c: The probability of being the acquirer (medium-tax target ${ }^{3}$ ) of a given medium-tax target (given acquirer) in a cross-border M\&A is higher for CFC rule MNEs

\footnotetext{
${ }^{3}$ A "medium-tax target" is a target, which is located in a country with an STR above the minimum low tax rate threshold but below the STR of the specific acquirer country.
} 
compared to non-CFC rule MNEs. Additionally, the probability of being the acquirer of a target in a country with a higher STR than in the acquirer's country is lower for CFC rule acquirers than for non-CFC rule acquirers.

\subsection{Empirical approach}

Our empirical approach to analyze the probability of being the actual acquirer country among several candidate acquirer countries follows the common assumption in M\&A literature that M\&As reflect synergies from combining two firms with all assets being priced at their fair value (e.g., Mitchell and Mulherin (1996), Becker and Fuest (2010), Feld et al. (2016a)) where

$V_{i j k}=\alpha C F C_{i j}+\beta b x_{i j k}+\varepsilon_{i j k}$

is the value of target $k$ in country $j$ if it was owned by an acquirer from country $i{ }^{4}$ The term $C F C_{i j}$ reflects the higher burden of potential taxation of target income due to CFC rules in the acquirer country $i$ if the target is located in country $j$. The variable vector $x_{i j k}$ contains various country control variables to capture owner-country-specific synergies realized through a potential M\&A. $\varepsilon_{i j k}$ is the residual. Coefficients $\alpha$ and $\beta$ are the estimated parameters. In this approach, the target is the same for every concerned M\&A; therefore, we automatically account for target firm, target country and time fixed effects. Hence, these fixed effects do not need to be included. We control for acquirer country fixed effects. In robustness checks, we also include specific target and acquirer firm controls.

We use the fact that a foreign firm from country $i$ will acquire a target if the value for this target is higher than for any other candidate acquirer from country $h$, i.e.,

$V_{i j k} \geq V_{h j k}, \forall h \in(1, \ldots, I)$,

where $I$ indicates the number of candidate acquirer countries. We analyze the probability that a particular acquirer buys a target, depending on potential application of CFC rules in the country of that particular acquirer and given that we know that the transaction takes place, which is given by:

$P\left(V_{i j k}>V_{h j k} \mid X\right)=\frac{\exp \left(\alpha C F C_{i j}+\beta X_{i j k}\right)}{\sum_{l=1}^{I} \exp \left(\alpha C F C_{l j}+\beta X_{l j k}\right)} \quad \forall h \in(1, \ldots, I)$.

Expression (3) considers a choice model assuming that M\&As reflect synergies from combining two firms and that acquirers value the individual firms and the M\&A correctly at their fair value. Using conditional logit and mixed logit regression models, we aim to calculate $P\left(V_{i j k}>V_{h j k} \mid X\right) .^{5}$

\footnotetext{
${ }^{4}$ We suppress a time subscript $t$ in the interest of readability of the model.

${ }^{5}$ The presented multinomial choice model is based on Feld et al. (2016a), p. 15.
} 
In our first approach, the difference between CFC rules is shown by a treatment effect using a simple dummy variable if a CFC rule is enacted in the acquirer country $i$ and is potentially applicable on target income, i.e., the STR in target country $j$ is below the minimum low tax rate threshold of the CFC rule of the candidate acquirer country $i$. Hence, the first variable of interest is constructed as

$C F C^{\text {dummy }}= \begin{cases}1, & \text { if } t_{i_{\text {threshold }}}>t_{j} \text { or country i applies } C F C \\ \text { rules without a tax rate threshold } \\ 0, \quad \text { otherwise, }\end{cases}$

where $t_{i_{\text {threshold }}}$ is the tax rate threshold of the CFC rule of the candidate acquirer country $i$ and $t_{j}$ is the STR in the target country $j$.

In our first approach, the treatment effect is assumed to be homogenous. In our second approach, we consider heterogeneity by using the tax rate differential between the home and host countries as a finer metering of the treatment. In particular, we consider the additional taxes payable due to CFC rule application if the target is used as a profit shifting vehicle ${ }^{6}$ :

$C F C^{\text {diff }}= \begin{cases}\tau_{i}-\tau_{j}, & \text { if } t_{i_{\text {threshold }}}>t_{j} \text { or country } i \text { applies } C F C \\ 0, & \text { rules without a tax rate threshold } \\ \text { otherwise. }\end{cases}$

For both approaches, we expect a negative sign of the regression coefficients $\alpha$ according to Hypothesis $1 \mathrm{a}$ and $1 \mathrm{~b}$ derived in Section 3.1.

In a third step, to address Hypothesis 1c, we take a different approach and split up the targets into three groups: Group (1) contains targets with STRs below the low tax rate threshold of the CFC rule; group (2) contains targets with STRs below the acquirer STRs but above the tax rate threshold of the CFC rule; group (3) contains targets with STRs higher than the acquirer STRs if the acquirer country applies CFC rules. Figure 2 illustrates this target grouping.

\footnotetext{
${ }^{6} \tau_{i}-\tau_{j}$ (and not $\tau_{i}$ ) are the additional taxes because the observed CFC rules grant a credit for the taxes paid by the foreign subsidiary in its host country.
} 
Figure 2. Target location among the three groups.

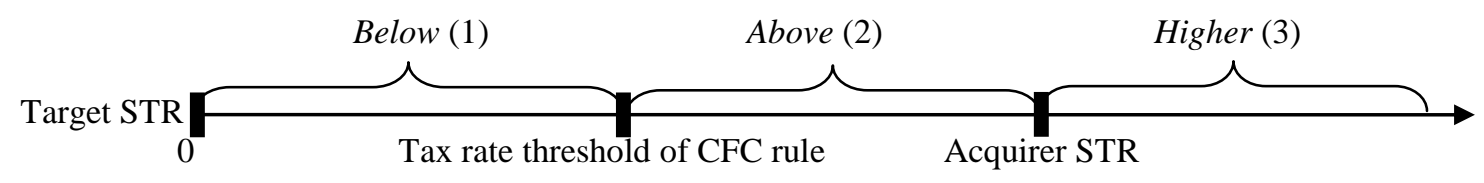

Below $= \begin{cases}\tau_{i}-\tau_{j}, & \text { if } t_{i_{\text {threshold }}}>t_{j} \text { or country i applies CFC } \\ & \text { rules without a tax rate threshold AND } t_{i}>t_{j} \\ & \text { otherwise, }\end{cases}$

Above $= \begin{cases}\tau_{i}-\tau_{j}, & \text { if } t_{i_{\text {threshold }}}<t_{j} A N D t_{i}>t_{j} \\ 0, & \text { otherwise, }\end{cases}$

Higher $= \begin{cases}\tau_{j}-\tau_{i}, & \text { if } t_{i}<t_{j} \text { and country } i \text { applies } C F C \text { rules } \\ 0, & \text { otherwise },\end{cases}$

If the target $\operatorname{STR}\left(\tau_{j}\right)$ is below the tax rate threshold of the CFC rule, there is additional taxation in the acquirer country at the acquirer STR $\left(\tau_{i}\right)$ as already shown in (5). We expect a negative coefficient of Below since these targets are unattractive to acquire from a CFC rule perspective.

If $\tau_{j}$ is above the tax rate threshold of the CFC rule but below $\tau_{i}$, the acquirer could shift profits to the target and reduce his effective tax burden by $\tau_{i}-\tau_{j}$. We expect a positive coefficient of Above as profits could be shifted - without CFC rule application - to the target, which may be particularly attractive for CFC rule acquirers.

If $\tau_{j}$ is higher than $\tau_{i}$, profit shifting in the here observed way to the target does not make sense as the target resides in a higher taxed country. We expect a negative coefficient of Higher since the high-tax target is unattractive for $\mathrm{CFC}$ rule acquirers from a tax perspective. Moreover, non-CFC rule acquirers could be more prone to acquire such targets as these acquirers may shift profits out of the high-tax target.

In our robustness test, we check whether our results are robust to considering effective average tax rates (EATRs) as CFC rules usually take into account the effective tax burden of the foreign low-tax subsidiary. Since we do not observe the effective tax burden of the targets, we use country-level EATRs from the Oxford University Centre for Business Taxation to determine whether a target may fall under the scope of CFC rules:

$C F C^{\text {diffEATR }}= \begin{cases}\tau_{i}-\tau_{j}, & \text { if } t_{i_{\text {threshold }}}>t_{j_{E A T R}} \text { or country } i \text { applies } C F C \\ & \text { rules without a tax rate threshold } \\ 0, & \text { otherwise. }\end{cases}$ 
In a further robustness test, we consider the scope of income included by the CFC rule. While some CFC rules only include passive income of the subsidiary, some CFC rules include passive and active income. Therefore, we let the treatment effect differ in this regard:

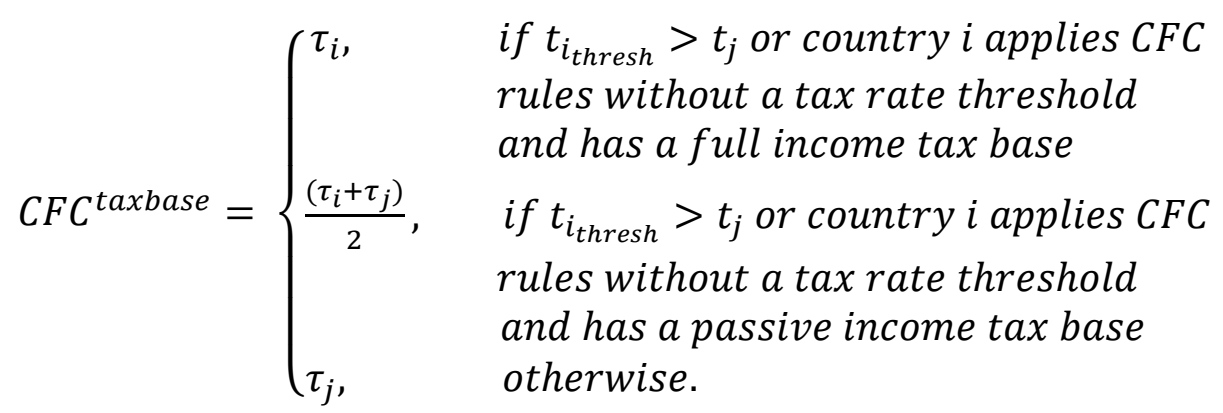

According to this differentiation, all targets are taxed at their STR. Further, this differentiation takes into account the additional CFC rule tax burden-assuming that active and passive income in the target are at the same height - in the following way: If CFC rules include the full target income once triggered, the total tax burden is set to the acquirer STR. If CFC rules include only target's passive income once triggered, the total tax burden is set to the average between target and acquirer STR.

The approach presented above takes an acquirer perspective by analyzing why a given target is bought by an acquirer from a specific country (Hypothesis 1a). In a second analysis, we follow the same logic but take a target perspective by analyzing why a given acquirer chooses to buy a target from a specific country (Hypothesis $1 \mathrm{~b}){ }^{7}$

Following Feld et al. (2016a) and Arulampalam et al. (2017), we include several control variables in both perspectives. We control for STR and economic indicators, such as GDP per capita, GDP growth, stock market capitalization per GDP and credits granted to private sector per GDP in the country of the candidate acquirer (or target), depending on whether the acquirer (or target) perspective is taken. Further, we control for several distance variables, such as the distance between the acquirer and target country, whether the acquirer and target have a common language, whether the acquirer and target were ever in a colonial relationship and whether the legal system of the acquirer and target country have common legal origins. In the target perspective, we additionally include variables to control for the institutional framework of the candidate target country, such as corruption control, business start-up costs, unemployment rate and number of listed domestic firms.

\subsection{Data}

Data for the empirical analysis is taken from the Thomson Financial SDC database, which contains worldwide M\&A transactions. We have selected all completed M\&As for the period 2002 to 2014 through which majority control $(>50 \%)$ of the targets has been attained. ${ }^{8}$

\footnotetext{
${ }^{7}$ Such a target perspective is also taken by Arulampalam et al. (2017).

${ }^{8}$ All observed CFC rules have a participation threshold below or equal to $50 \%$ so that the majority control requirement of CFC rules is always fulfilled.
} 
Further, for each M\&A, country of the acquirer ultimate parent, direct acquirer, target ultimate parent and direct target must be given. ${ }^{9}$ In addition, we require that the acquirer ultimate parent and the target reside in different countries and that the acquirer ultimate parent and direct acquirer reside in the same country to reduce the possibility of a subsidiary in a third country involved in the M\&A. To keep the mixed logit regressions computationally feasible, the set of considered candidate acquirer countries (Hypothesis 1a) or candidate target countries (Hypothesis 1b) is restricted to the 30 most frequent acquirer or target locations. ${ }^{10}$ These restrictions leave a sample of 14,421 cross-border M\&As involving 55 countries to investigate Hypothesis 1a and a sample of 13,447 cross-border M\&As involving 54 countries to investigate Hypothesis 1b. Table 2 and Table 8 give an overview over the number of acquirer ultimate parents and targets in the respective cross-border M\&A sample per country. In line with di Giovanni (2005), we observe that countries with the largest financial markets have most observations in both samples. Further, these tables provide information on whether CFC rules are implemented in those countries.

Data on CFC rules is based on IBFD European Tax Handbook (2002-2016), various corporate tax guides (Ernst \& Young (2004-2016), Deloitte (2015), KPMG (2016)) and the specific tax law of each country. We have sampled various dimensions of CFC rules for the period 2002 to 2014, such as:

- tax rate threshold that triggers CFC rule,

- country lists that trigger (blacklists) or do not trigger (whitelists) CFC rule,

- threshold for passive-to-active-income ratio that triggers CFC rule,

- whether active or only passive income of CFCs is included at the parent level, or

- $\quad$ significant exemptions to CFC rule.

\subsection{Results}

\subsubsection{Acquirer perspective}

Table 4 presents the baseline results of different multinomial choice models to test Hypothesis 1a on the influence of CFC rules on the likelihood of being the acquirer country of a given target (acquirer perspective). For each deal, the dependent variable equals one for the actual acquirer country of origin and zero for all other counterfactual acquirer countries. For definitions, data sources and summary statistics of all variables see Table 3.

In the conditional logit regression (1), CFC dummy from expression (4) is the variable of interest, which indicates potential taxation via CFC rules in the acquirer country. We observe a negative coefficient, which suggests that potential taxation in the acquirer country due to CFC rule application has a negative influence on the probability of being the acquirer country

\footnotetext{
${ }^{9}$ Throughout our paper, we use the terms "ultimate parent" and "parent" synonymously.

${ }^{10}$ To investigate Hypothesis 1a, important control variables are missing for Guernsey, Luxembourg and Taiwan so that we effectively consider 27 candidate acquirer countries. To investigate Hypothesis 1b, important control variables are missing for Indonesia and Sweden so that we effectively consider 28 candidate target countries.
} 
for a given target. To be more specific, we consider $C F C^{\text {diff }}$ from expression (5) in regression (2). $C F C^{\text {diff }}$ measures the magnitude of a potential additional tax burden due to CFC rule application and the coefficient is significantly negative. The substantially lower $p$ value of $C F C^{\text {diff }}(p<0.000 \%)$ compared to $C F C^{\text {dummy }}(p=19.9 \%)$ is probably due to introducing heterogeneity to the treatment effect by considering the specific tax rate differential between the acquirer and target country in case CFC rules apply. The coefficient of -1.4569 implies that if the target is potentially treated by CFC rules and the difference between acquirer STR and target STR increases by $1 \%$, the likelihood of acquiring this targets decreases by $0.05 \%$. Taken together, we provide evidence that potential CFC rule application on a target's income reduces the probability of acquiring this target; this finding supports Hypothesis 1a. However, the calculated economic effect seems to be very low for small STR differences.

As argued in Feld et al. (2016a), a violation of the assumption of the independence of irrelevant alternatives (IIA) in the conditional logit model could be problematic because estimates may be biased. Consequently, we randomize our variables of interest by using a mixed logit estimator. This randomization follows a normal distribution with mean $g$ and covariance $\boldsymbol{W}$; the parameters are estimated by simulated maximum likelihood with 50 Halton draws. ${ }^{11}$ In our mixed logit regressions, we observe that the estimated standard deviations of the normal distribution are highly significant; therefore, we prefer this approach and apply mixed logit regressions in the remaining regressions.

In regression (3), we observe that applying the mixed logit model does not change the basic results as $C F C^{\text {diff }}$ remains significantly negative at the $1 \%$ level and quantitatively stable. In regression (4), we cluster the standard errors at the target-country/year level and observe that $C F C^{\text {diff }}$ is significant at the 5\% level. In regression (5), we split the targets as described in expressions (6), (7) and (8). Figure 3 shows a kernel density estimate of the simulated coefficients of the variables of interest. The significantly negative coefficient of Below confirms the results from previous regressions and also the significantly negative coefficient of Higher is as expected. This finding shows that it is less likely that a CFC rule acquirer buys a target, which is located in a country with a higher STR than the CFC rule acquirer. This finding supports Hypothesis 1c. However, the significantly negative coefficient of Above is counterintuitive as we hypothesized that firms from CFC rule countries are more likely to be the acquirer if the target is located in a country with an STR below the acquirer STR but above the tax rate threshold of the CFC rule. Hence, we reject Hypothesis $1 \mathrm{c}$ in the acquirer perspective.

\footnotetext{
${ }^{11}$ In untabulated regression results, we find that using 100 Halton draws produces very similar results in both the acquirer and target perspective; these results are available upon request.
} 
Figure 3. Distribution of coefficients of Below, Above and Higher (acquirer perspective).

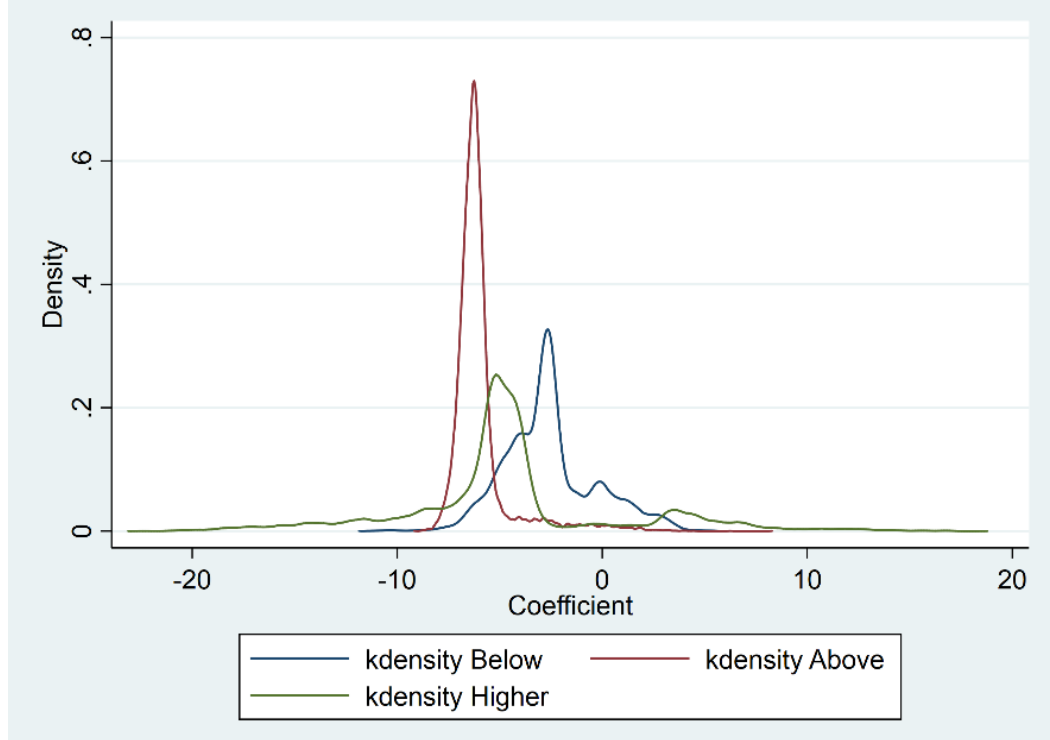

This figure provides a graph of the Epanechnikov kernel density function of the simulated coefficients of Below, Above and Higher in regression (5) of Table 4 using simulated maximum likelihood with 50 Halton draws. The mean (standard deviation) of the simulated coefficients is $-2.59(0.40)$ for Below, -5.83 (1.20) for Above and -4.55 (0.66) for Higher. Density is on the $y$-axis and the coefficient is on the $x$-axis.

Most control variables are highly significant and show the expected signs. Regarding STR, we find a negative effect on the likelihood to be the successful bidder if the bidder is located in a high-tax country. This finding is in line with Becker and Riedel (2012), who find a negative effect of parent STR on investment in foreign subsidiaries. Helpman et al. (2004) show that the productivity level of firms influences their investments abroad and firms with the highest productivity engage in FDI. Similar to other studies, we use InGDPpercapita and GDPgrowth as proxies for productivity levels in an acquirer country and find that InGDPpercapita has a significantly positive coefficient, while GDPgrowth is insignificant. Hence, a high level of GDP per capita has a positive impact on cross-border M\&A activity. StockmarketSize has the expected positive coefficient, which indicates that well-developed stock markets in the acquirer country offer good financing conditions to raise capital to fund cross-border M\&As. The size of the private credit market captured by PrivateCredit has an insignificant effect. Cross-border M\&A literature finds that lower bilateral transaction costs between the acquirer and target due to less cultural and geographic distance positively affect M\&A activity (e.g., di Giovanni (2005)). In line with these findings, we observe that InDistance, CommonLanguage, ColonialRelationship, CommonLegalSystem show the expected signs and are highly significant.

Table 5 provides the results of our check on whether our baseline results are robust to specification variations. In regression (1), we include a dummy variable capturing the unilateral method (i.e., the credit or exemption method on foreign dividends) to avoid double 
taxation on foreign dividends. The significantly positive coefficient of ExemptionMethod indicates that the likelihood of being the acquirer increases if the acquirer resides in a country that exempts foreign dividends of the target from taxation, which is in line with the result of Feld et al. (2016a). In regressions (2), (3) and (4), we vary the calculation of our variable of interest by considering target effective average tax rates $\left(C F C^{\text {diffEATR}}\right)$, potential nonapplication of CFC rules within the EEA $\left(C F C^{\text {diffEEA }}\right)^{12}$ and the included income by CFC rules $\left(C F C^{\text {taxbase }}\right)$. In regression (5), we additionally randomize STR and in regression (6), we exclude acquirers from Australia, Canada and New Zealand because their CFC rules do not explicitly mention a tax rate threshold, where our identification is coming from. Regression (7) excludes the largest acquirer countries (Canada, United Kingdom and United States), which account for around half of our observations. The exclusion of the US further checks for a potential bias due to the so-called check-the-box rule, which was introduced in the US in 1997 and may allow for an escape from CFC rules for US MNEs under specific circumstances by using hybrid entities (e.g., Altshuler and Grubert (2006), Mutti and Grubert (2009)). We observe that all robustness tests validate our baseline results, both quantitatively and qualitatively.

Table 6 provides further robustness tests. In regression (1), we exclude all control variables except for the acquirer country fixed effects to check if there is a bias due to correlation between $C F C^{\text {diff }}$ and the control variables. We find that $C F C^{\text {diff }}$ decreases substantially and remains significant. Further, we check whether our results are robust to differentiating between profitable and loss-making targets in regression (2). Due to missing firm level variables, the sample decreases substantially. We find that the coefficients of $C F C$ profitable and $C F C^{\text {non_profitable }}$ remain significantly negative. Interestingly, the effect is more pronounced for loss-making targets; the difference between the coefficients is significant at a $p$-value of $1.9 \%$ (two-sided). One possible reason could be that non-CFC rule acquirers are more interested in acquiring low-tax loss-making targets than CFC rule acquirers, because non-CFC rule acquirers may shift profits to the loss-making targets and, thereby, net out the losses - or even use existing loss carryforwards if possible - of these targets. Finally, regressions (3), (4) and (5) control for target-specific financial data (total assets, return on assets, sales and earnings before interest, taxes, depreciation and amortization) by interacting these consolidated profit and loss statement and balance sheet items with each candidate acquirer country. While again the sample size decreases substantially, we observe that $C F C^{\text {diff }}$ remains significantly negative.

\subsubsection{Target perspective}

With the same econometric idea as in Section 3.4.1 but with a target perspective, we analyze for each given acquirer the origin of the eventual target country among a choice set of various

\footnotetext{
${ }^{12}$ Ruf and Weichenrieder (2013) investigate the Cadbury-Schweppes ruling of the European Court of Justice in 2007, which triggered a substantial mitigation of the application of CFC rules within the European Economic Area (EEA). In line with this argumentation, the authors find evidence for a relative increase in passive investments in low-tax EEA subsidiaries and a parallel decrease in passive investments in non-EEA subsidiaries.
} 
target countries (target perspective). Table 10 presents the baseline results of different multinomial choice models to test Hypothesis $1 \mathrm{~b}$ on the influence of CFC rules on the likelihood of being chosen as the target country of a given acquirer. For each deal, the dependent variable equals one for the actual target country of origin and zero for all other counterfactual target countries. For definitions, data sources and summary statistics of all variables see Table 9. Due to a different perspective and additional control variables, the data set differs from the former data set in Section 3.4.1.

In the conditional logit regression (1), $C F C^{\text {dummy }}$ has a significantly negative coefficient, which indicates that potential CFC rule application on a candidate target's income has a negative effect on actually choosing the target country as a location. $C F C^{\text {diff }}$ measures in more detail the magnitude of a potential additional tax burden due to CFC rule application and-similar to the result in Section 3.4.1- the significance level increases compared to the mere dummy variable approach $\left(C F C^{d u m m y}\right)$. In line with Hypothesis $1 \mathrm{~b}$, this finding indicates that potential CFC rule application on target's income negatively influences the target location choice of a given acquirer. From a global perspective and with an increasing number of countries introducing or strengthening CFC rules, this finding may further indicate higher overall tax revenue due to less profit shifting opportunities.

To cope with a possible violation of the IIA (see Section 3.4.1), we use again a mixed logit estimator and randomize our variables of interest in the remaining regressions. Again, we observe that the estimated standard deviations of the normal distribution are highly significant; therefore, we prefer this approach and apply mixed logit regressions in the remaining regressions. We observe a further decrease of $C F C^{\text {diff } f}$ and the significance level remains stable in regression (3) and regression (4), where we cluster the standard errors at the acquirer-country/year level. In regression (5), we observe a similar pattern as in Section 3.4.1 and Figure 4 shows a kernel density estimate of the simulated coefficients of the variables of interest. Again, the coefficients of Below and Higher are significantly negative, which is in line with Hypothesis 1c and suggests that the likelihood of target location choice decreases if the target potentially falls under the scope of CFC rule or has a higher STR than the acquirer. However, we again observe that Above is significantly negative, which is counterintuitive, because we would expect that targets are more likely to be acquired if they are located in a country with an STR below the acquirer STR but above the tax rate threshold of the acquirer's CFC rule. Hence, also in the target perspective, we reject Hypothesis 1c. 
Figure 4. Distribution of coefficients of Below, Above and Higher (target perspective).

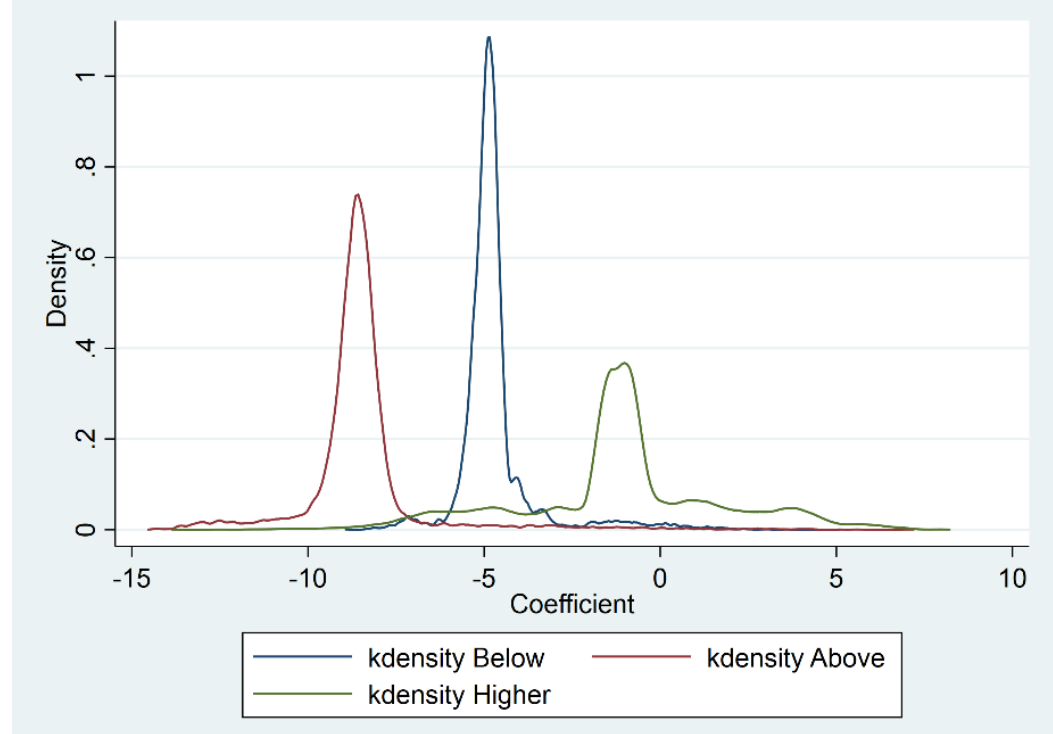

This figure provides a graph of the Epanechnikov kernel density function of the simulated coefficients of Below, Above and Higher in regression (5) of Table 10 using simulated maximum likelihood with 50 Halton draws. The mean (standard deviation) of the simulated coefficients is $-4.71(0.60)$ for Below, -8.61 (1.00) for Above and -1.15 (0.54) for Higher. Density is on the $y$-axis and the coefficient is on the $x$-axis.

Regarding significant control variables, we observe that STR has a positive effect on target location choice, which is an unexpected result as FDI literature generally suggests a negative effect of host country STR on host country investment (e.g., Feld and Heckemeyer (2011)). An explanation for this result could be that cross-border M\&As are less sensitive to host country STRs (e.g., Hebous et al. (2011), Herger et al. (2016)) or that profit shifting structures within the acquiring MNE mitigate this effect (e.g., Arulampalam et al. (2017)). Additionally, variation of STR is also used to compose our variable of interest, which may lead to interdependencies. Finally, the significantly positive effect of STR does not prove to be robust.

Regarding control variables, InGDPpercapita and StockmarketSize have insignificant coefficients, whereas GDPgrowth has a significantly positive effect in some regressions, i.e., targets located in growing economies are more likely to be acquired. Further, PrivateCredit has a significantly negative effect on target location choice. The explanation for this finding may be the following: If a target is located in a country with a low ratio of private credits granted to the private sector, the supply of credits may be limited. Consequently, credit supply for internal expansion is limited, which makes targets in these countries more likely to be acquired (Arulampalam et al. (2017)). Similar to the findings in Section 3.4.1, we observe that lower bilateral transaction costs between the acquirer and target positively affect target location choice: InDistance, CommonLanguage and ColonialRelationship have the expected significant coefficient; CommonLegalSystem has an expected positive though insignificant 
estimate. Finally, the control variables for the institutional framework in the candidate target country have significant explanatory power. A high degree of corruption control, a large number of listed firms and low business start-up costs increase the chances to be chosen as target location; unemployment rate has an insignificant effect.

In Table 11, we provide similar robustness tests as in Table 5 and yield similar results. Regressions (1), (2), and (3) take into account target effective average tax rates $\left(C F C^{\text {diffEATR }}\right)$, potential non-application of CFC rules within the EEA $\left(C F C^{\text {diffEEA }}\right)$ and the included income by $C F C$ rules $\left(C F C^{\text {taxbase }}\right)$. In regression (4), we additionally randomize $S T R$ and in regression (5), we exclude acquirers from Australia, Canada and New Zealand because their CFC rules do not explicitly mention a tax rate threshold. Regression (6) excludes the largest target countries (Germany, United Kingdom and United States), which account for almost half of our observations. In regression (7), we include BusinessDisclosure as a further variable for the institutional framework in the candidate target country. This variable is not included in our baseline results since its inclusion significantly drops the observation number. We observe that all robustness tests resemble our baseline results, both quantitatively and qualitatively.

Table 12 provides further robustness tests yielding similar results as presented in Table 6. In regression (1), we exclude all control variables except for the target country fixed effects to check if there is a bias due to correlation between $C F C^{\text {diff }}$ and the control variables. Again, we find that $C F C^{\text {diff }}$ decreases substantially and remains significant. Further, we check whether our results are robust to differentiating between profitable and loss-making targets in regression (2). We find that the coefficients of $C F C^{\text {profitable }}$ and $C F C^{\text {non }}$ profitable remain significantly negative; however, in this robustness test, there is no significant difference between the coefficients of $C F C^{\text {profitable }}$ and $C F C^{\text {non_profitable }}$. Finally, in regressions (3), (4) and (5), we include acquirer-specific financial data (total assets, return on assets, sales and earnings before interest, taxes, depreciation and amortization) by interacting these consolidated profit and loss statement and balance sheet items with each candidate target country. We again observe a substantial sample decrease due missing firm level variables, but the results prove to be robust.

\section{CFC rules and the direction of cross-border M\&As}

\subsection{Hypothesis development}

In this section, we consider the direction of cross-border M\&As. In particular, we investigate whether CFC rules affect the decision which firm becomes the parent firm of a newly created MNE through a cross-border M\&A. Following the finding of Voget (2011) that CFC rules trigger the relocation of headquarters, we argue that CFC rules negatively influence the direction of a cross-border M\&A between two firms from different countries, i.e., we expect that it is more probable that the non-CFC rule firm acquires the CFC rule firm. The reasoning is as follows: If the non-CFC rule firm becomes the new MNE's parent, potential (new) profit 
shifting strategies may arise by setting up or using an already existing tax haven subsidiary within the MNE, which potentially decreases the overall tax burden. These (new) profit shifting strategies would not exist if the CFC rule firm became the acquirer due to potential CFC rule application on low-tax subsidiaries' income. We, therefore, hypothesize the following, stated in alternative form:

Hypothesis 2: The probability of being the acquiring firm in cross-border M\&As is higher for firms in non-CFC rule countries compared to firms in CFC rule countries.

This analysis is different to the analysis presented in Section 3, where we investigate whether CFC rules affect the decision to acquire a target if CFC rules are potentially applied to this target's income. By analyzing the effect of CFC rules on the direction of cross-border M\&As, we consider whether CFC rules negatively affect the choice of who becomes the parent of the newly created MNE.

\subsection{Empirical approach}

To analyze the direction of observed cross-border M\&As, we assume that firm $a$ acquires firm $b$ and that $a$ and $b$ do not reside in the same country. Under the assumption that M\&As reflect synergies from combining these two firms and that investors value the individual firms and the M\&A correctly, it follows that the value when $a$ acquires $b\left(V_{a b}\right)$ is higher than the value when $b$ acquires $a\left(V_{b a}\right)$, i.e., $V_{a b}-V_{b a}>0$. Based on Hypothesis 2 derived under 4.1, we argue that CFC rules have an impact on this valuation. In particular, CFC rules lead to a competitive disadvantage for parent firms as those firms have less profit shifting opportunities within their group and have to fear potential CFC rule application on low-tax subsidiaries' income, at which these laws are aiming. We consider the following expression to analyze the direction in cross-border M\&As, depending on the CFC rules of the two involved firms and given that we know that the transaction takes place:

$$
\begin{array}{r}
P\left(V_{a b}>V_{b a} \mid X\right)=E(Y \mid \Delta C F C+\Delta X)=\frac{\exp (\beta(\Delta C F C+\Delta X))}{1+\exp (\beta(\Delta C F C+\Delta X))} \\
Y\left\{\begin{array}{l}
1 \text { if } V_{a b}-V_{b a}>0 \\
0 \text { if } V_{a b}-V_{b a} \leq 0
\end{array}\right.
\end{array}
$$

Using logit regression models, we aim to calculate $P\left(V_{a b}>V_{b a} \mid X\right)$, i.e., we always consider the setting that $a$ acquires $b\left(V_{a b}-V_{b a}>0\right.$ in expression (11)). This consideration implies that $\mathrm{y}$, our dependent variable, always takes the value $1 .{ }^{13}$ The variable of interest is $\triangle C F C$, which measures the difference in CFC rules between $a$ and $b$. We consider two approaches in calculating $\triangle C F C$.

First, we construct a CFC dummy variable ( $\left.\triangle C F C \_d u m m y\right)$ that measures whether CFC rules are present in the residence countries of $a$ and $b$. If, for example, the country of $a$ does not

\footnotetext{
${ }^{13}$ The presented binary choice model is based on Huizinga and Voget (2009), pp. 1229ff.
} 
apply CFC rules (0) and the country of $b$ applies CFC rules (1) in the M\&A year, $\triangle C F C \_d u m m y$ takes the value $0-1=-1$.

Second, we consider individual characteristics of $\mathrm{CFC}$ rules to allow for more heterogeneity among CFC rules. We construct a CFC variable ( $\triangle C F C_{-}$value), which is zero for non-CFC rule countries and one for $\mathrm{CFC}$ rule countries. In addition to that, we consider the $\mathrm{CFC}$ rule countries in more detail and group them regarding their CFC rule harshness among the two main CFC rule features, which can be derived from all observed CFC rules: The lowest possible tax haven STR and the passive-to-active-income ratio accepted by CFC rules. This approach can increase $\triangle C F C_{-}$value up to the value 3. Among the CFC rule countries, the lowest possible tax haven STR is set to the tax rate threshold of the CFC rule. ${ }^{14}$ For CFC rule countries with a tax haven STR equal or above its median value of $15 \%$, we add 1 to $\triangle C F C \_$value. Similarly, we consider the passive-to-active-income ratio, which determines the amount of passive income that is allowed so that $\mathrm{CFC}$ rules are not triggered. The median value of the passive-to-active-income ratio is $10 \%$; for CFC rule countries with a passive-toactive-income ratio below $10 \%$, we add 1 to $\triangle C F C_{-}$value. ${ }^{15}$ Table 1 provides one country example for each of the four categories of $\triangle C F C_{-} v a l u e$.

Table 1. Country examples for the four categories of $\triangle C F C \_v a l u e$.

\begin{tabular}{llccc}
\hline $\begin{array}{l}\Delta C F C_{-} \text {value of } \\
\text { country }\end{array}$ & Exemplary country & CFC rules? & $\begin{array}{c}\text { Tax rate } \\
\text { threshold }>15 \% ?\end{array}$ & $\begin{array}{c}\text { Passive-to-active- } \\
\text { income ratio }<10 \% ?\end{array}$ \\
\hline 0 & Netherlands & no & n/a & n/a \\
1 & China (from 2008) & yes (since 2008) & no $(12.5 \%)$ & no $(50 \%)$ \\
2 & Korea, Rep. & yes & yes $(15 \%)$ & no $(50 \%)$ \\
3 & Japan & yes & yes $(20 \%)$ & yes (no ratio) \\
\hline
\end{tabular}

If, for example, a firm residing in the Netherlands acquires a firm residing in the Republic of Korea, $\triangle C F C$ _value takes the value $0-2=-2$. We expect a negative coefficient for both $\triangle C F C \_d u m m y$ and $\triangle C F C_{-}$value, indicating that it is more likely that the firm without $\mathrm{CFC}$ rules or with less harsh $\mathrm{CFC}$ rules becomes the acquiring firm.

Following Huizinga and Voget (2009), we control for firm characteristics and macroeconomic conditions in the two countries captured by $\Delta X$. On the firm level, we include the firms' consolidated financial data. We control for relative size of the two firms $(\Delta$ Size) and expect a positive coefficient, as larger firms are considered more likely to acquire smaller firms. $\Delta$ Leverage considers the difference in leverage ratio between the two firms. Following Desai and Hines (2002), we argue that firms with higher leverage have lower borrowing costs. Thus, these firms have higher borrowing capacity, which makes them more likely to be the acquirer.

\footnotetext{
${ }^{14}$ For EEA Member States in the years after the decision of the European Court of Justice in the case "CadburySchweppes" (C-194/04) in 2006, we set the tax haven tax rate equal to the lowest STR within the EU, because since this decision, CFC rules are de facto not applicable within the EU. In support of this reasoning, Ruf and Weichenrieder (2013) provide evidence for an increase of profit shifting within the EEA after this decision (see footnote 12).

${ }^{15}$ These thresholds are subjective; however, they split the CFC rule countries into two equal halves and allow a grouping of the $\mathrm{CFC}$ rule countries according to their relative CFC rule harshness.
} 
$\triangle P T I$ measures the relative difference between pre-tax income of the two firms. Similar to our expectation of $\Delta$ Size, we expect that firms with higher profits are more likely to acquire firms with lower profits.

On the country-level, we control for the difference in STRs $(\triangle S T R)$. We have no expectation on its coefficient as high-tax countries may have a better investment environment whereas low-tax country may attract firms due to tax savings. Based on the finding of Huizinga and Voget (2009) that taxation of dividend repatriation affects M\&A direction, we include the difference in both countries' double taxation avoidance method on foreign dividends $(\triangle D T M)$, where 0 (1) stands for the credit (exemption) method. We expect a positive coefficient for this variable. We also include the two countries' relative stock market size ( $\Delta$ StockMrk), which proxies for the relative ease to raise capital at stock markets and we expect a positive coefficient. In addition, we include the two countries' relative difference between domestic credits granted to the private sector $(\Delta$ CreditMrk). Similar to the argumentation in Section 3.4.2, we argue that if a company is located in a country with a low ratio of credits granted to the private market, the supply of credit may be limited and, hence, the possibility to finance an acquisition via credit is limited. Thus, we expect a positive coefficient. Finally, to control for the price level in an economy, we include the difference in the inflation rate ( $\Delta$ Inflation) between both countries. We have a negative expectation on its coefficient.

Further, we include country fixed effects that reflect whether the country is the acquirer or the target country: For each M\&A, the acquirer country gets the value of 1 and the target country gets the value of -1 ; all other countries get the value of 0 for the respective $M \& A$.

Following Huizinga and Voget (2009), our logit regression is estimated using maximum likelihood estimation without a constant. The reason is straightforward: Since we always consider the setting that firm $a$ acquires firm $b\left(V_{a b}-V_{b a}>0\right.$ in expression (11)), the dependent variable is always one and, consequently, there is no variation in the dependent variable and the constant would be a perfect fit.

\subsection{Data}

The M\&A data analyzed in this section are the same as described in Section 3.3 with two exceptions. First, we relax the restriction to the 30 most frequent acquirer or target locations. Second, we require that the direct acquirer and the direct target reside in the same country as their respective ultimate parent to reduce the possibility of a subsidiary in a third country being involved in the M\&A. In addition, as outlined above, we need consolidated financial data of both firms as control variables, which reduces our sample to 1,199 cross-border M\&As involving 30 countries. ${ }^{16}$ Table 14 gives an overview over the number of acquirer

\footnotetext{
${ }^{16}$ We experience this sharp decrease in cross-border M\&A observation due to the lack of important financial control variables. However, this decrease is not due to specific countries or a specific financial control variable. Hence, we assume that the smaller sub-sample is a representative subset of the larger one and that focusing on this subset does not bias our subsequent empirical work. This argumentation follows Huizinga and Voget (2009), p. 1228, who face the same problem using firm level data in an SDC data set and who observe a similar decrease
} 
ultimate parents and target ultimate parents in this cross-border M\&A sample per country. Further, this table provides information on whether CFC rules are implemented in those countries.

\subsection{Results}

Table 16 shows the results of the binary choice model to test Hypothesis 2 on the influence of CFC rules on the direction of cross-border M\&As between two firms, i.e., which firm becomes the acquirer. For definitions, data sources and summary statistics of all variables see Table 15.

In regressions (1) and (2), we find that CFC rules negatively affect the probability which firm becomes the acquirer. In particular, we find a significant coefficient at the $5 \%$ level for $\triangle C F C$ value. This finding suggests that when two firms perform a cross-border M\&A, it is less likely that the firm with the harsher CFC rule becomes the acquiring firm. For the dummy variable approach $\left(\triangle C F C \_d u m m y\right)$, we observe a significantly negative coefficient at the $10 \%$ level. Hence, also the mere presence of CFC rules seems to affect cross-border M\&A direction. These results prove to be robust in regressions (3) and (4), where we analyze a slightly smaller sample by considering only cross-border M\&As directly between the ultimate parents, i.e., the acquirer is the acquirer ultimate parent and the target is the target ultimate parent. In regressions (5) and (6), we consider the same setting as in regressions (3) and (4), but exclude M\&As that involve the United States. We do this to check that the results are not biased by potential check-the-box rule application in the US, which may allow for an escape from CFC rules for US MNEs under specific circumstances by using hybrid entities (e.g., Altshuler and Grubert (2006), Mutti and Grubert (2009)). Although this exclusion decreases the sample by more than half, we still observe a significantly negative estimate for $\triangle C F C \_d u m m y$. The coefficient of $\triangle C F C \_$value remains also negative; however, its $p$-value drops to $19.4 \%$.

Taken together, we provide evidence for Hypothesis 2 that the direction of cross-border M\&As between firms is negatively affected by the presence and harshness of CFC rules. This finding contributes to previous research documenting that headquarters relocation is influenced by CFC rules (Voget (2011)). Our interpretation of this finding is that if the nonCFC rule firm acquirers the CFC rule firm, new profit shifting opportunities may potentially come up within the newly formed MNE, which may decrease the tax burden in the future. If the $\mathrm{CFC}$ rule firm acquires the non-CFC rule firm, these profit shifting opportunities are rather unattractive due to $\mathrm{CFC}$ rules in the new parent country. In addition, the CFC rule firm has to fear potential CFC rule application on low-tax subsidiaries' income if such subsidiaries are already present in the acquired firm. The firms involved in the M\&As are quite large with

in sample size. To expand our sub-sample, we follow Huizinga and Voget (2009) and use Compustat North America and Compustat Global databases that are together global in coverage to fill-up firm level control variables. We use CUSIP and SEDOL firm identification codes to link the Compustat databases with the SDC database. 
an average value of total assets of the acquirers (targets) of 38.3 (2.4) bio. USD. Hence, it is reasonable to assume that at least some of the involved firms are already MNEs with implemented profit shifting strategies within their group if no CFC rules are present in the ultimate parent country.

Regarding control variables, we find, as expected, that firm size has a significantly positive impact on the likelihood of being the acquiring firm and, in most regressions, firm profitability, firm leverage, STR and stock market size have a significantly positive effect on M\&A direction. Credit market size has an unexpected negative effect in most regressions. We observe non-significant estimates for inflation rate and the method to avoid double taxation.

\section{Conclusion}

In this study, we investigate the impact of an increasingly important anti tax avoidance measure on cross-border M\&A activity of corporations on a global scale. In particular, we consider important characteristics of CFC rules from a variety of countries and apply different logit regression models on a large worldwide cross-border M\&A data set. Considering individual M\&As, we find that the probability of being the acquirer of low-tax targets decreases if CFC rules may be applicable on this target's income. This finding implies that acquirers from non-CFC rule countries have a competitive advantage in bidding for targets in low-tax countries. This is explained by a higher reservation price of these non-CFC rules acquirers due to potential firm value increasing profit shifting opportunities after the M\&A. Further, we show that the acquirer's location choice of a target is negatively affected if the target may fall under the scope of CFC rules of an acquirer. The reasoning behind this result is the same as before but the underlying perspective is different. Thereby, we find evidence that $\mathrm{CFC}$ rules affect $\mathrm{M} \& \mathrm{~A}$ activity on the bidding side, i.e., non-CFC rule acquirers have competitive advantages in bidding for a given target, and on the target side, i.e., low-tax targets are rather acquired by non-CFC rule acquirers. These two findings provide robust evidence that CFC rules distort ownership of low-tax targets. Finally, we show that CFC rules negatively affect the direction of cross-border M\&A, i.e., countries with CFC rules are less likely to attract parent firms in a newly created MNE after M\&As.

However, our results should not necessarily be interpreted as suggesting that countries should get rid of CFC rules. Moreover, our findings suggest that $\mathrm{CFC}$ rules seem to reach the intended goal of reducing profit shifting opportunities with low-tax subsidiaries in our cross border M\&A context. In other words, our results suggest that the specific way of investing in foreign low-tax countries to shift profits afterwards is limited by existing CFC rules in the acquirer country. Therefore, $\mathrm{CFC}$ rules can be used by countries to counteract tax avoidance behavior of their MNEs, which could result in an increase in tax revenue on an overall scale.

Nevertheless, the parallel presence and non-presence of CFC rules across countries is problematic from an economic perspective due to competitive disadvantages on the crossborder M\&A market and potentially tax-biased ownership structures on a global scale. 
Thereby, we contribute to a strand of literature where little research has been undertaken so far. Further, our findings are particularly interesting in light of current tax policy developments. While the BEPS project of the OECD suggests an implementation of effective CFC rules in the OECD and G20 countries (OECD/G20 (2015)), the European Council even issued a legally binding directive requiring EU member states to implement CFC rules by 2019 (European Council (2016)). In other words, at the latest from 2019 onwards, firms residing in the EU may face competitive disadvantages in M\&A activities due to tax legislation, compared to firms residing in OECD and G20 member states, which do not follow the BEPS project's suggestion to implement effective CFC rules and lower their MNEs' tax avoidance opportunities. This finding indicates that more coordination regarding countries' international tax law seems to be necessary if tax avoidance behavior of MNEs is considered unfavorable on a global scale and intended measures to counteract this behavior are supposed to be fruitful. 


\section{Appendix}

Table 2. Cross-border M\&A sample (2002-2014) for analyzing effect of acquirer CFC rules on probability of being acquirer country (Section 3.4.1).

\begin{tabular}{|c|c|c|c|c|c|c|c|}
\hline Country & $\begin{array}{l}\text { CFC } \\
\text { rule }\end{array}$ & $\begin{array}{l}\text { Number of } \\
\text { acquirers }\end{array}$ & $\begin{array}{c}\text { Number of } \\
\text { targets }\end{array}$ & Country & $\begin{array}{l}\text { CFC } \\
\text { rule }\end{array}$ & $\begin{array}{l}\text { Number of } \\
\text { acquirers }\end{array}$ & $\begin{array}{c}\text { Number of } \\
\text { targets }\end{array}$ \\
\hline Australia & 1 & 923 & 663 & Japan & 1 & 529 & 166 \\
\hline Austria & 0 & 125 & 73 & Korea, Rep. & 1 & 187 & 147 \\
\hline Belarus & $\mathrm{n} / \mathrm{a}$ & $\mathrm{n} / \mathrm{a}$ & 6 & Latvia & $\mathrm{n} / \mathrm{a}$ & $\mathrm{n} / \mathrm{a}$ & 2 \\
\hline Belgium & 0 & 154 & 186 & Lithuania & $\mathrm{n} / \mathrm{a}$ & $\mathrm{n} / \mathrm{a}$ & 14 \\
\hline Bermuda & $\mathrm{n} / \mathrm{a}$ & $\mathrm{n} / \mathrm{a}$ & 29 & Malaysia & 0 & 212 & 157 \\
\hline Brazil & $\mathrm{n} / \mathrm{a}$ & $\mathrm{n} / \mathrm{a}$ & 251 & Malta & $\mathrm{n} / \mathrm{a}$ & $\mathrm{n} / \mathrm{a}$ & 4 \\
\hline British Virgin Islands & $\mathrm{n} / \mathrm{a}$ & $\mathrm{n} / \mathrm{a}$ & 70 & Mexico & $\mathrm{n} / \mathrm{a}$ & $\mathrm{n} / \mathrm{a}$ & 197 \\
\hline Bulgaria & $\mathrm{n} / \mathrm{a}$ & $\mathrm{n} / \mathrm{a}$ & 30 & Netherlands & 0 & 421 & 355 \\
\hline Canada & 1 & 1,124 & 1,074 & New Zealand & 1 & 68 & 196 \\
\hline Cayman Islands & $\mathrm{n} / \mathrm{a}$ & $\mathrm{n} / \mathrm{a}$ & 17 & Norway & 1 & 296 & 144 \\
\hline Chile & $\mathrm{n} / \mathrm{a}$ & $\mathrm{n} / \mathrm{a}$ & 95 & Panama & $\mathrm{n} / \mathrm{a}$ & $\mathrm{n} / \mathrm{a}$ & 10 \\
\hline China & 1 & 338 & 846 & Poland & $\mathrm{n} / \mathrm{a}$ & $\mathrm{n} / \mathrm{a}$ & 140 \\
\hline Croatia & $\mathrm{n} / \mathrm{a}$ & $\mathrm{n} / \mathrm{a}$ & 20 & Portugal & $\mathrm{n} / \mathrm{a}$ & $\mathrm{n} / \mathrm{a}$ & 69 \\
\hline Cyprus & $\mathrm{n} / \mathrm{a}$ & $\mathrm{n} / \mathrm{a}$ & 16 & Russian Federation & 0 & 39 & 112 \\
\hline Czech Republic & $\mathrm{n} / \mathrm{a}$ & $\mathrm{n} / \mathrm{a}$ & 81 & Seychelles & $\mathrm{n} / \mathrm{a}$ & $\mathrm{n} / \mathrm{a}$ & 2 \\
\hline Denmark & 1 & 42 & 158 & Singapore & 0 & 490 & 271 \\
\hline Estonia & $\mathrm{n} / \mathrm{a}$ & $\mathrm{n} / \mathrm{a}$ & 12 & Slovak Republic & $\mathrm{n} / \mathrm{a}$ & $\mathrm{n} / \mathrm{a}$ & 16 \\
\hline Finland & 1 & 62 & 142 & Slovenia & $\mathrm{n} / \mathrm{a}$ & $\mathrm{n} / \mathrm{a}$ & 15 \\
\hline France & 1 & 644 & 667 & South Africa & $\mathrm{n} / \mathrm{a}$ & $\mathrm{n} / \mathrm{a}$ & 119 \\
\hline Germany & 1 & 622 & 842 & Spain & 1 & 324 & 360 \\
\hline Greece & $\mathrm{n} / \mathrm{a}$ & $\mathrm{n} / \mathrm{a}$ & 25 & Sweden & 1 & 71 & 369 \\
\hline Hong Kong SAR, China & 0 & 560 & 343 & Switzerland & 0 & 344 & 209 \\
\hline Hungary & $\mathrm{n} / \mathrm{a}$ & $\mathrm{n} / \mathrm{a}$ & 45 & Taiwan, China & $\mathrm{n} / \mathrm{a}$ & $\mathrm{n} / \mathrm{a}$ & 105 \\
\hline Iceland & $\mathrm{n} / \mathrm{a}$ & $\mathrm{n} / \mathrm{a}$ & 3 & Turkey & $\mathrm{n} / \mathrm{a}$ & $\mathrm{n} / \mathrm{a}$ & 79 \\
\hline India & 0 & 337 & 214 & Ukraine & $\mathrm{n} / \mathrm{a}$ & $\mathrm{n} / \mathrm{a}$ & 31 \\
\hline Ireland & 0 & 342 & 152 & United Kingdom & 1 & 1,670 & 1,772 \\
\hline Israel & 1 & 206 & 129 & United States & 1 & 4,020 & 2,857 \\
\hline Italy & 1 & 271 & 314 & Total & & 14,421 & 14,421 \\
\hline
\end{tabular}

Table shows number of acquirer ultimate parents and targets per country in our cross-border M\&A sample to investigate Hypothesis 1a. In this context, cross-border M\&As are defined as acquirer ultimate parent and target residing in different countries; the direct acquirer and acquirer ultimate parent reside in the same country. CFC rule takes the value one, if the country has implemented CFC rules in 2014. 


\begin{tabular}{|c|c|c|c|c|c|c|c|}
\hline Variable & Definition & Data source & Obs. & Mean & Std. Dev. & Min & Max \\
\hline$C F C^{\text {dummy }}$ & $\begin{array}{l}\text { Binary dummy variable coded one if target country STR is smaller than acquirer country's tax rate } \\
\text { threshold of CFC rule or acquirer country applies CFC rules without a tax rate threshold, and } 0 \\
\text { otherwise }\end{array}$ & Tax guides & 317,835 & 0.111 & 0.315 & 0 & 1 \\
\hline$C F C^{\text {diff }}$ & $\begin{array}{l}\text { Difference between acquirer country STR and target country STR if target country STR is smaller than } \\
\text { acquirer country's tax rate threshold of CFC rule or acquirer country applies CFC rules without a tax } \\
\text { rate threshold, and } 0 \text { otherwise }\end{array}$ & Tax guides & 317,835 & 0.012 & 0.043 & 0.000 & 0.409 \\
\hline$C F C^{\text {diffEATR }}$ & $\begin{array}{l}\text { Difference between acquirer country STR and target country STR if target country EATR is smaller } \\
\text { than acquirer country's tax rate threshold of the CFC rule or acquirer country applies CFC rules } \\
\text { without a tax rate threshold, and } 0 \text { otherwise }\end{array}$ & $\begin{array}{l}\text { Tax guides; Oxford } \\
\text { University Centre for } \\
\text { Business Taxation }\end{array}$ & 317,835 & 0.011 & 0.039 & -0.011 & 0.409 \\
\hline$C F C^{\operatorname{diffEEA}}$ & $\begin{array}{l}\text { Same as } C F C^{\text {diff }} \text {; however, set to zero if acquirer and target country are both EEA Member States and } \\
\text { M\&A year is after } 2006\end{array}$ & Tax guides & 317,835 & 0.012 & 0.042 & 0.000 & 0.409 \\
\hline Below & See expression (6) & Tax guides & 317,835 & 0.012 & 0.043 & 0.000 & 0.409 \\
\hline Above & See expression (7) & Tax guides & 317,835 & 0.010 & 0.029 & 0.000 & 0.273 \\
\hline Higher & See expression (8) & Tax guides & 317,835 & 0.015 & 0.031 & 0.000 & 0.155 \\
\hline CFC taxbase & See expression (10) & Tax guides & 317,835 & 0.318 & 0.066 & 0.000 & 0.409 \\
\hline$C F C^{\text {profitable }}$ & Same as $C F C^{\text {diff }}$; however, for non-profitable targets set to zero & $\begin{array}{l}\text { Tax guides; SDC; } \\
\text { Compustat North America; } \\
\text { Compustat Global }\end{array}$ & 55,715 & 0.007 & 0.034 & 0.000 & 0.395 \\
\hline CFC $C^{\text {non_profitable }}$ & Same as $C F C^{\text {diff }}$; however, for profitable targets set to zero & $\begin{array}{l}\text { Tax guides; SDC; } \\
\text { Compustat North America; } \\
\text { Compustat Global }\end{array}$ & 55,715 & 0.003 & 0.021 & 0.000 & 0.409 \\
\hline STR & STR in candidate acquirer country, including typical local taxes & Tax guides & 317,835 & 0.291 & 0.071 & 0.125 & 0.409 \\
\hline ExemptionMethod & $\begin{array}{l}\text { Binary dummy variable coded one if candidate acquirer country unilaterally applies the exemption } \\
\text { method to avoid double taxation of foreign dividends, and } 0 \text { if it unilaterally applies the credit method }\end{array}$ & Tax guides & 294,697 & 0.606 & 0.489 & 0 & 1 \\
\hline InGDPpercapita & GDP per capita in candidate acquirer country (natural logarithm) & Wo & 317,835 & 10.416 & 0.620 & 7.942 & 11.284 \\
\hline GDPgrowth & Growth of GDP in candidate acquirer country (in \%) & World Bank & 317,835 & 3.095 & 3.168 & -7.821 & 15.240 \\
\hline StockmarketSize & alization of listed domestic companies in candidate ac & Bank & 317,835 & 121.5 & 175.6 & 15.767 & $1,254$. \\
\hline PrivateCredit & Domestic credit to private sector in candidate acquirer country (in \% of GDP) & World Bank & 317,835 & 115.3 & 39.525 & 31.081 & 233.4 \\
\hline InDistance & $\begin{array}{l}\text { Simple distance (in } \mathrm{km} \text { ) between most populated cities of candidate acquirer and target country } \\
\text { (natural logarithm) }\end{array}$ & Mayer and Zignago (2011) & 317,835 & 8.498 & 1.100 & 4.088 & 9.883 \\
\hline CommonLanguage & $\begin{array}{l}\text { Common language index between candidate acquirer and target country ( } 0 \text { (low similarity) to } 1 \text { (high } \\
\text { similarity)) }\end{array}$ & Melitz and Toubal (2014) & 317,835 & 0.242 & 0.217 & 0.000 & 0.983 \\
\hline ColonialRelationship & $\begin{array}{l}\text { Binary dummy variable coded one if candidate acquirer and target country were ever in a colonial } \\
\text { relationship, and } 0 \text { otherwise }\end{array}$ & Mayer and Zignago (2011) & 317,835 & 0.095 & 0.294 & 0 & 1 \\
\hline CommonLegalSystem & $\begin{array}{l}\text { Binary dummy variable coded one if legal system of candidate acquirer and target country have } \\
\text { common legal origins, and } 0 \text { otherwise }\end{array}$ & Head et al. (2010) & 317,835 & 0.319 & 0.466 & 0 & 1 \\
\hline TargetAssets & $\begin{array}{l}\text { Pre-deal consolidated target total assets in the last year before the effective M\&A date (natural } \\
\text { logarithm) }\end{array}$ & $\begin{array}{l}\text { SDC; Compustat North } \\
\text { America; Compustat Global }\end{array}$ & 52,809 & 18.118 & 2.297 & 11.513 & 28.060 \\
\hline TargetROA & $\begin{array}{l}\text { Pre-deal consolidated target pre-tax income in the last year before the effective M\&A date divided by } \\
\text { pre-deal consolidated target total assets in the last year before the effective M\&A date }\end{array}$ & $\begin{array}{l}\text { SDC; Compustat North } \\
\text { America; Compustat Global }\end{array}$ & 52,809 & -0.036 & 0.844 & -11.800 & 18.000 \\
\hline TargetSales & Pre-deal consolidated target net sales in the last year before the effective $M \& A$ date (natural logarithm) & $\begin{array}{l}\text { SDC; Compustat North } \\
\text { America; Compustat Global }\end{array}$ & 78,495 & 17.667 & 2.320 & 6.908 & 26.216 \\
\hline TargetEBITDA & $\begin{array}{l}\text { Pre-deal consolidated target EBITDA (earnings before interest, taxes, depreciation and amortization) in } \\
\text { the last year before the effective M\&A date (natural logarithm) }\end{array}$ & $\begin{array}{l}\text { SDC; Compustat North } \\
\text { America; Compustat Global }\end{array}$ & 34,405 & 16.369 & 2.093 & 7.601 & 24.300 \\
\hline
\end{tabular}


Table 4. Effect of acquirer CFC rules on probability of being acquirer country (Section 3.4.1).

\begin{tabular}{|c|c|c|c|c|c|}
\hline Explanatory variables & $\begin{array}{c}\text { (1) } \\
\text { Conditional logit }\end{array}$ & $\begin{array}{c}\text { (2) } \\
\text { Conditional logit }\end{array}$ & $\begin{array}{c}\text { (3) } \\
\text { Mixed logit }\end{array}$ & $\begin{array}{c}\text { (4) } \\
\text { Mixed logit }\end{array}$ & $\begin{array}{c}\text { (5) } \\
\text { Mixed logit }\end{array}$ \\
\hline$C F C^{\text {dummy }}$ & $\begin{array}{l}-0.0523^{\mathrm{a}} \\
(0.0407)\end{array}$ & & & & \\
\hline$C F C^{\text {diff }}$ & & $\begin{array}{c}-1.4569 * * * \\
(0.3277)\end{array}$ & $\begin{array}{c}-1.2387 * * * \\
(0.3482)\end{array}$ & $\begin{array}{c}-1.2387 * * \\
(0.5606)\end{array}$ & \\
\hline Below & & & & & $\begin{array}{c}-2.5882 * * * \\
(0.4015)\end{array}$ \\
\hline Above & & & & & $\begin{array}{c}-5.8277 * * * \\
(1.1959)\end{array}$ \\
\hline Higher & & & & & $\begin{array}{c}-4.5472 * * * \\
(0.6634)\end{array}$ \\
\hline$S T R$ & $\begin{array}{c}-2.0538 * * * \\
(0.6319)\end{array}$ & $\begin{array}{c}-1.7568 * * * \\
(0.6330)\end{array}$ & $\begin{array}{c}-2.0903 * * * \\
(0.6442)\end{array}$ & $\begin{array}{c}-2.0903 * * \\
(0.8423)\end{array}$ & $\begin{array}{c}-1.9648 * * * \\
(0.7104)\end{array}$ \\
\hline InGDPpercapita & $\begin{array}{c}1.0541 * * * \\
(0.1619)\end{array}$ & $\begin{array}{c}1.0452 * * * \\
(0.1625)\end{array}$ & $\begin{array}{l}1.1104 * * * \\
(0.1652)\end{array}$ & $\begin{array}{l}1.1104 * * * \\
(0.2118)\end{array}$ & $\begin{array}{c}1.1838 * * * \\
(0.1710)\end{array}$ \\
\hline GDPgrowth & $\begin{array}{l}-0.0034 \\
(0.0076)\end{array}$ & $\begin{array}{l}-0.0032 \\
(0.0075)\end{array}$ & $\begin{array}{l}-0.0041 \\
(0.0076)\end{array}$ & $\begin{array}{l}-0.0041 \\
(0.0099)\end{array}$ & $\begin{array}{l}-0.0041 \\
(0.0078)\end{array}$ \\
\hline StockmarketSize & $\begin{array}{c}0.0005 * * * \\
(0.0002)\end{array}$ & $\begin{array}{c}0.0005 * * * \\
(0.0002)\end{array}$ & $\begin{array}{c}0.0005^{* * * *} \\
(0.0002)\end{array}$ & $\begin{array}{c}0.0005 \\
(0.0003)\end{array}$ & $\begin{array}{l}0.0005 * * * \\
(0.0002)\end{array}$ \\
\hline PrivateCredit & $\begin{array}{c}0.0007 \\
(0.0006)\end{array}$ & $\begin{array}{c}0.0006 \\
(0.0006)\end{array}$ & $\begin{array}{c}0.0007 \\
(0.0006)\end{array}$ & $\begin{array}{c}0.0007 \\
(0.0011)\end{array}$ & $\begin{array}{c}0.0005 \\
(0.0007)\end{array}$ \\
\hline InDistance & $\begin{array}{c}-0.5852 * * * \\
(0.0114)\end{array}$ & $\begin{array}{c}-0.5789 * * * \\
(0.0115)\end{array}$ & $\begin{array}{c}-0.5906 * * * \\
(0.0119)\end{array}$ & $\begin{array}{c}-0.5906 * * * \\
(0.0217)\end{array}$ & $\begin{array}{c}-0.6185^{* * * *} \\
(0.0128)\end{array}$ \\
\hline CommonLanguage & $\begin{array}{c}1.8148 * * * \\
(0.0620)\end{array}$ & $\begin{array}{c}1.8112 * * * \\
(0.0620)\end{array}$ & $\begin{array}{l}1.8494 * * * \\
(0.0629)\end{array}$ & $\begin{array}{c}1.8494 * * * \\
(0.1289)\end{array}$ & $\begin{array}{c}1.9616 * * * \\
(0.0653)\end{array}$ \\
\hline ColonialRelationship & $\begin{array}{c}0.3020 * * * \\
(0.0360)\end{array}$ & $\begin{array}{c}0.2868 * * * \\
(0.0359)\end{array}$ & $\begin{array}{c}0.2994 * * * \\
(0.0364)\end{array}$ & $\begin{array}{c}0.2994 * * * \\
(0.0569)\end{array}$ & $\begin{array}{c}0.3168 * * * \\
(0.0378)\end{array}$ \\
\hline CommonLegalSystem & $\begin{array}{l}0.1029 * * * \\
(0.0251)\end{array}$ & $\begin{array}{c}0.1145 * * * \\
(0.0252)\end{array}$ & $\begin{array}{c}0.1117 * * * \\
(0.0254)\end{array}$ & $\begin{array}{l}0.1117 * * \\
(0.0470)\end{array}$ & $\begin{array}{c}0.1107 * * * \\
(0.0259)\end{array}$ \\
\hline Acquirer country fixed effects & YES & YES & YES & YES & YES \\
\hline Observations & 317,835 & 317,835 & 317,835 & 317,835 & 317,835 \\
\hline Log-likelihood & $-32,188$ & $-32,178$ & $-32,165$ & $-32,165$ & $-32,091$ \\
\hline
\end{tabular}

Regressions of probability of being the acquirer country on (potential) CFC rule application; see expression (3). For each deal, the dependent variable equals one if country $i$ is the actual acquirer's country of origin, and zero if country $i$ is a counterfactual acquirer country. For variable definitions and data sources, see Table 3. Only cross-border M\&As where the direct acquirer country is equal to the acquirer ultimate parent country are considered. All regressions control for acquirer country fixed effects, which are available upon request. The variables of interest follow a random distribution in the mixed logit regressions. Regressions (1) and (2) are estimated by a conditional logit model and regressions (3), (4) and (5) are estimated by a mixed logit model. Regression (4) is identical to regression (3) except for standard errors, which are robust to clustering on the targetcountry-year level. *,**, and *** denote statistical significance at 10\%, 5\%, and 1\% levels, respectively. Robust standard errors are provided in parentheses.

${ }^{a}$ The level of statistical significance is $19.9 \%$. 
Table 5. Robustness tests of effect of acquirer CFC rules on probability of being acquirer country (Section 3.41).

\begin{tabular}{|c|c|c|c|c|c|c|c|}
\hline Explanatory variables & $\begin{array}{c}\text { (1) } \\
\text { Controlling for } \\
\text { double taxation } \\
\text { avoidance method }\end{array}$ & $\begin{array}{c}(2) \\
\text { Using target effective } \\
\text { average tax rate }\end{array}$ & $\begin{array}{c}(3) \\
\text { Considering EAA } \\
\text { exemption (post } \\
\text { 2006) } \\
\end{array}$ & $\begin{array}{c}\text { (4) } \\
\text { Considering included } \\
\text { income of CFC rule }\end{array}$ & $\begin{array}{c}\text { (5) } \\
\text { Randomizing STR }\end{array}$ & $\begin{array}{c}\text { (6) } \\
\text { Excl. } \\
\text { acquirers from } \\
\text { AU\&CA\&NZ }\end{array}$ & $\begin{array}{c}\text { (7) } \\
\text { Excl. } \\
\text { acquirers from } \\
\text { CA\&UK\&US }\end{array}$ \\
\hline$C F C^{\text {diff }}$ & $\begin{array}{l}-0.6035^{*} \\
(0.3472)\end{array}$ & & & & $\begin{array}{c}-1.2130 * * * \\
(0.3507)\end{array}$ & $\begin{array}{c}-1.6977 * * * \\
(0.3588)\end{array}$ & $\begin{array}{l}-1.0453^{*} \\
(0.5643)\end{array}$ \\
\hline$C F C^{\text {diffEATR }}$ & & $\begin{array}{c}-1.2961 * * * \\
(0.3162)\end{array}$ & & & & & \\
\hline$C F C^{\operatorname{diffEEA}}$ & & & $\begin{array}{c}-1.5406 * * * \\
(0.3491)\end{array}$ & & & & \\
\hline$C F C^{\text {taxbase }}$ & & & & $\begin{array}{c}-1.7810 * * * \\
(0.3993)\end{array}$ & & & \\
\hline STR & $\begin{array}{c}-2.3967 * * * \\
(0.6431)\end{array}$ & $\begin{array}{c}-1.9075 * * * \\
(0.6363)\end{array}$ & $\begin{array}{l}-1.9575 * * * \\
(0.6440)\end{array}$ & $\begin{array}{c}-2.0217 * * * \\
(0.6433)\end{array}$ & $\begin{array}{c}-2.1346 * * * \\
(0.6472)\end{array}$ & $\begin{array}{l}-1.6298 * * \\
(0.6774)\end{array}$ & $\begin{array}{c}-1.9436 * * * \\
(0.7260)\end{array}$ \\
\hline ExemptionMethod & $\begin{array}{c}0.8440 * * * \\
(0.0859)\end{array}$ & & & & & & \\
\hline InGDPpercapita & $\begin{array}{l}1.2497 * * * \\
(0.1661)\end{array}$ & $\begin{array}{l}1.0501 * * * \\
(0.1621)\end{array}$ & $\begin{array}{c}1.1225 * * * \\
(0.1655)\end{array}$ & $\begin{array}{c}1.1152 * * * \\
(0.1653)\end{array}$ & $\begin{array}{c}1.0906 * * * \\
(0.1666)\end{array}$ & $\begin{array}{l}1.1571^{* * * *} \\
(0.1680)\end{array}$ & $\begin{array}{l}1.0672 * * * \\
(0.1805)\end{array}$ \\
\hline GDPgrowth & $\begin{array}{l}-0.0071 \\
(0.0077)\end{array}$ & $\begin{array}{l}-0.0034 \\
(0.0076)\end{array}$ & $\begin{array}{l}-0.0040 \\
(0.0076)\end{array}$ & $\begin{array}{l}-0.0044 \\
(0.0076)\end{array}$ & $\begin{array}{l}-0.0046 \\
(0.0077)\end{array}$ & $\begin{array}{c}0.0051 \\
(0.0085)\end{array}$ & $\begin{array}{l}-0.0106 \\
(0.0086)\end{array}$ \\
\hline StockmarketSize & $\begin{array}{c}0.0006 * * * \\
(0.0002)\end{array}$ & $\begin{array}{l}0.0005^{* * * *} \\
(0.0002)\end{array}$ & $\begin{array}{l}0.0005^{* * * *} \\
(0.0002)\end{array}$ & $\begin{array}{c}0.0005 * * * \\
(0.0002)\end{array}$ & $\begin{array}{l}0.0005 * * * \\
(0.0002)\end{array}$ & $\begin{array}{l}0.0004 * * * \\
(0.0002)\end{array}$ & $\begin{array}{c}0.0003 * * \\
(0.0002)\end{array}$ \\
\hline PrivateCredit & $\begin{array}{l}0.0012 * \\
(0.0007)\end{array}$ & $\begin{array}{c}0.0006 \\
(0.0006)\end{array}$ & $\begin{array}{c}0.0007 \\
(0.0006)\end{array}$ & $\begin{array}{c}0.0007 \\
(0.0006)\end{array}$ & $\begin{array}{c}0.0007 \\
(0.0007)\end{array}$ & $\begin{array}{c}0.0006 \\
(0.0008)\end{array}$ & $\begin{array}{c}0.0010 \\
(0.0010)\end{array}$ \\
\hline InDistance & $\begin{array}{c}-0.5657 * * * \\
(0.0121)\end{array}$ & $\begin{array}{c}-0.5890 * * * \\
(0.0115)\end{array}$ & $\begin{array}{c}-0.5884 * * * \\
(0.0119)\end{array}$ & $\begin{array}{c}-0.5948 * * * \\
(0.0119)\end{array}$ & $\begin{array}{c}-0.5919 * * * \\
(0.0119)\end{array}$ & $\begin{array}{c}-0.5696^{* * * *} \\
(0.0143)\end{array}$ & $\begin{array}{c}-0.6515 * * * \\
(0.0175)\end{array}$ \\
\hline CommonLanguage & $\begin{array}{c}1.9151 * * * \\
(0.0641)\end{array}$ & $\begin{array}{l}1.8596 * * * \\
(0.0625)\end{array}$ & $\begin{array}{l}1.8491 * * * \\
(0.0630)\end{array}$ & $\begin{array}{c}1.8603 * * * \\
(0.0631)\end{array}$ & $\begin{array}{l}1.8598 * * * \\
(0.0627)\end{array}$ & $\begin{array}{l}1.9419 * * * \\
(0.0676)\end{array}$ & $\begin{array}{l}2.2097 * * * \\
(0.0770)\end{array}$ \\
\hline ColonialRelationship & $\begin{array}{l}0.2454 * * * \\
(0.0370)\end{array}$ & $\begin{array}{l}0.3005^{* * * *} \\
(0.0360)\end{array}$ & $\begin{array}{c}0.2971 * * * \\
(0.0364)\end{array}$ & $\begin{array}{l}0.3004 * * * \\
(0.0365)\end{array}$ & $\begin{array}{l}0.2937 * * * \\
(0.0371)\end{array}$ & $\begin{array}{l}0.2334 * * * \\
(0.0388)\end{array}$ & $\begin{array}{c}0.4303 * * * \\
(0.0475)\end{array}$ \\
\hline CommonLegalSystem & $\begin{array}{c}0.0946^{* * * *} \\
(0.0258)\end{array}$ & $\begin{array}{c}0.1030 * * * \\
(0.0251)\end{array}$ & $\begin{array}{c}0.1139 * * * \\
(0.0254)\end{array}$ & $\begin{array}{c}0.1136 * * * \\
(0.0254)\end{array}$ & $\begin{array}{c}0.1122 * * * \\
(0.0256)\end{array}$ & $\begin{array}{c}0.1244 * * * \\
(0.0258)\end{array}$ & $\begin{array}{c}0.1925^{* * * *} \\
(0.0277)\end{array}$ \\
\hline $\begin{array}{l}\text { Acquirer country fixed effects } \\
\text { Observations }\end{array}$ & $\begin{array}{c}\text { YES } \\
294,697\end{array}$ & $\begin{array}{l}\text { YES } \\
317,835\end{array}$ & $\begin{array}{l}\text { YES } \\
317,835\end{array}$ & $\begin{array}{l}\text { YES } \\
317,835\end{array}$ & $\begin{array}{l}\text { YES } \\
317,835\end{array}$ & $\begin{array}{c}\text { YES } \\
243,136\end{array}$ & $\begin{array}{c}\text { YES } \\
151,651\end{array}$ \\
\hline Log-likelihood & $-30,936$ & $-32,175$ & $-32,164$ & $-32,161$ & $-32,164$ & $-25,945$ & $-19,203$ \\
\hline
\end{tabular}


Table 6. Further robustness tests of effect of acquirer CFC rules on probability of being acquirer country (Section 3.4.1).

\begin{tabular}{|c|c|c|c|c|c|}
\hline Explanatory variables & $\begin{array}{c}(1) \\
\text { Excl. } \\
\text { control } \\
\text { variables }\end{array}$ & $\begin{array}{c}(2) \\
\text { Profitable vs. } \\
\text { non-profitable } \\
\text { targets }\end{array}$ & $\begin{array}{c}(3) \\
\text { Incl. target } \\
\text { assets \& target } \\
\text { return on assets }\end{array}$ & $\begin{array}{c}\text { (4) } \\
\text { Incl. target } \\
\text { sales }\end{array}$ & $\begin{array}{c}\text { (5) } \\
\text { Incl. target } \\
\text { EBITDA }\end{array}$ \\
\hline$C F C^{\text {diff }}$ & $\begin{array}{c}-4.1258 * * * \\
(0.3294)\end{array}$ & & $\begin{array}{c}-3.1934 * * * \\
(1.1995)\end{array}$ & $\begin{array}{c}-2.8136 * * * * \\
(0.7548)\end{array}$ & $\begin{array}{l}-2.1391 * \\
(1.2086)\end{array}$ \\
\hline$C F C^{\text {profitable }}$ & & $\begin{array}{c}-1.9250 * * \\
(0.9653)\end{array}$ & & & \\
\hline$C F C^{\text {non_profitable }}$ & & $\begin{array}{c}-5.5943 * * * \\
(1.7488)\end{array}$ & & & \\
\hline STR & & $\begin{array}{c}0.8489 \\
(1.5131)\end{array}$ & $\begin{array}{c}0.4872 \\
(1.5582)\end{array}$ & $\begin{array}{c}-0.6872 \\
(1.2818)\end{array}$ & $\begin{array}{l}-0.5640 \\
(1.8920)\end{array}$ \\
\hline InGDPpercapita & & $\begin{array}{c}1.6639 * * * \\
(0.3762)\end{array}$ & $\begin{array}{c}1.8388 * * * * \\
(0.3851)\end{array}$ & $\begin{array}{c}1.2574 * * * \\
(0.3246)\end{array}$ & $\begin{array}{l}1.1308 * * \\
(0.5062)\end{array}$ \\
\hline GDPgrowth & & $\begin{array}{c}0.0383 * * \\
(0.0195)\end{array}$ & $\begin{array}{c}0.0455 * * \\
(0.0202)\end{array}$ & $\begin{array}{c}0.0166 \\
(0.0176)\end{array}$ & $\begin{array}{c}0.0272 \\
(0.0258)\end{array}$ \\
\hline StockmarketSize & & $\begin{array}{c}0.0003 \\
(0.0004)\end{array}$ & $\begin{array}{c}-0.0002 \\
(0.0005)\end{array}$ & $\begin{array}{l}-0.0000 \\
(0.0004)\end{array}$ & $\begin{array}{c}-0.0007 \\
(0.0006)\end{array}$ \\
\hline PrivateCredit & & $\begin{array}{c}0.0001 \\
(0.0017)\end{array}$ & $\begin{array}{c}0.0003 \\
(0.0018)\end{array}$ & $\begin{array}{l}-0.0010 \\
(0.0014)\end{array}$ & $\begin{array}{l}-0.0008 \\
(0.0023)\end{array}$ \\
\hline InDistance & & $\begin{array}{c}-0.5018 * * * \\
(0.0313)\end{array}$ & $\begin{array}{c}-0.4904 * * * \\
(0.0338)\end{array}$ & $\begin{array}{c}-0.4932 * * * * \\
(0.0266)\end{array}$ & $\begin{array}{c}-0.5148 * * * \\
(0.0422)\end{array}$ \\
\hline CommonLanguage & & $\begin{array}{c}1.7924 * * * \\
(0.1765)\end{array}$ & $\begin{array}{c}1.6550 * * * \\
(0.1951)\end{array}$ & $\begin{array}{c}1.5999 * * * \\
(0.1562)\end{array}$ & $\begin{array}{c}1.4257 * * * \\
(0.2360)\end{array}$ \\
\hline ColonialRelationship & & $\begin{array}{c}0.2783 * * * \\
(0.0862)\end{array}$ & $\begin{array}{c}0.2070 * * \\
(0.0921)\end{array}$ & $\begin{array}{c}0.1570 * * \\
(0.0731)\end{array}$ & $\begin{array}{l}0.1919 * \\
(0.1080)\end{array}$ \\
\hline CommonLegalSystem & & $\begin{array}{c}0.2239 * * * \\
(0.0654)\end{array}$ & $\begin{array}{c}0.3270 * * * \\
(0.0713)\end{array}$ & $\begin{array}{c}0.3013 * * * \\
(0.0560)\end{array}$ & $\begin{array}{c}0.3555 * * * \\
(0.0860)\end{array}$ \\
\hline Acquirer country fixed effects & YES & YES & YES & YES & YES \\
\hline Observations & 317,835 & 55,715 & 52,809 & 78,495 & 34,405 \\
\hline Log-likelihood & $-35,450$ & $-5,495$ & $-5,157$ & $-7,715$ & $-3,287$ \\
\hline
\end{tabular}

Regressions of probability of being the acquirer country on (potential) CFC rule application; see expression (3). For each deal, the dependent variable equals one if country $i$ is the actual acquirer's country of origin, and zero if country $i$ is a counterfactual acquirer country. For variable definitions and data sources, see Table 3. Only cross-border M\&As where the direct acquirer country is equal to the acquirer ultimate parent country are considered. All regressions control for acquirer country fixed effects, which are available upon request, and are estimated by a mixed logit model. The variables of interest follow a random distribution. Regression (1) drops all control variables and regression (2) distinguishes between profitable and non-profitable targets. Regression (3) includes the interaction between acquirer country fixed effects and TargetAssets and the interaction between acquirer country fixed effects and TargetROA. Regression (4) includes the interaction between acquirer country fixed effects and TargetSales. Regression (5) includes the interaction between acquirer country fixed effects and TargetEBITDA. The coefficients and standard errors of these interactions are shown in Table $7 . *^{* *}$, and *** denote statistical significance at $10 \%$, $5 \%$, and $1 \%$ levels, respectively. Robust standard errors are provided in parentheses. 
Table 7. Supplemental regression results for candidate acquirer country fixed effects interacted with target-specific financial data.

\begin{tabular}{|c|c|c|c|c|c|}
\hline \multicolumn{2}{|l|}{ Regression (3) of Table 6} & \multicolumn{2}{|c|}{ Regression (4) of Table 6} & \multicolumn{2}{|l|}{ Regression (5) of Table 6} \\
\hline Australia $*$ TargetAssets & $\begin{array}{c}-0.1275^{* * *} \\
(0.0526)\end{array}$ & Australia*TargetSales & $\begin{array}{c}-0.1167 * * * \\
(0.0417)\end{array}$ & Australia $*$ TargetEBITDA & $\begin{array}{c}-0.1229 * \\
(0.0696)\end{array}$ \\
\hline Austria*TargetAssets & $\begin{array}{c}0.0927 \\
(0.0960)\end{array}$ & Austria*TargetSales & $\begin{array}{c}0.0242 \\
(0.0851)\end{array}$ & Austria*TargetEBITDA & $\begin{array}{c}0.2592 * * \\
(0.1150)\end{array}$ \\
\hline Belgium*TargetAssets & $\begin{array}{c}0.0394 \\
(0.0890)\end{array}$ & Belgium $*$ TargetSales & $\begin{array}{l}-0.0256 \\
(0.0693)\end{array}$ & Belgium*TargetEBITDA & $\begin{array}{c}0.0561 \\
(0.1021)\end{array}$ \\
\hline Canada $*$ TargetAssets & $\begin{array}{c}-0.1606^{* * * *} \\
(0.0541)\end{array}$ & Canada $*$ TargetSales & $\begin{array}{c}-0.1735 * * * \\
(0.0380)\end{array}$ & Canada*TargetEBITDA & $\begin{array}{c}-0.1486^{* *} \\
(0.0643)\end{array}$ \\
\hline China $*$ TargetAssets & $\begin{array}{c}0.0502 \\
(0.0579)\end{array}$ & China*TargetSales & $\begin{array}{l}-0.0781 \\
(0.0507)\end{array}$ & China $*$ TargetEBITDA & $\begin{array}{l}-0.0301 \\
(0.1096)\end{array}$ \\
\hline Denmark $*$ TargetAssets & $\begin{array}{c}0.0591 \\
(0.1467)\end{array}$ & Denmark*TargetSales & $\begin{array}{c}0.0749 \\
(0.1215)\end{array}$ & Denmark*TargetEBITDA & $\begin{array}{c}0.0275 \\
(0.1813)\end{array}$ \\
\hline Finland ${ }^{*}$ TargetAssets & $\begin{array}{l}-0.0130 \\
(0.1863)\end{array}$ & Finland $*$ TargetSales & $\begin{array}{c}-0.1980 * * * \\
(0.0728)\end{array}$ & Finland $*$ TargetEBITDA & $\begin{array}{c}0.0561 \\
(0.0490)\end{array}$ \\
\hline France $*$ TargetAssets & $\begin{array}{c}0.1841 * * * \\
(0.0477)\end{array}$ & France $^{*}$ TargetSales & $\begin{array}{c}0.1561 * * * \\
(0.0420)\end{array}$ & France*TargetEBITDA & $\begin{array}{c}0.1999 * * * \\
(0.0603)\end{array}$ \\
\hline Germany*TargetAssets & $\begin{array}{c}0.1779 * * * \\
(0.0482)\end{array}$ & Germany*TargetSales & $\begin{array}{c}0.1239 * * * \\
(0.0479)\end{array}$ & Germany*TargetEBITDA & $\begin{array}{c}0.2245 \text { *** } \\
(0.0636)\end{array}$ \\
\hline HongKongSARChina*TargetAssets & $\begin{array}{l}-0.0375 \\
(0.0544)\end{array}$ & HongKongSARChina*TargetSales & $\begin{array}{c}-0.0809^{*} \\
(0.0477)\end{array}$ & HongKongSARChina $*$ TargetEBITDA & $\begin{array}{l}-0.0597 \\
(0.0725)\end{array}$ \\
\hline India $*$ TargetAssets & $\begin{array}{c}-0.1437 * * \\
(0.0591)\end{array}$ & India*TargetSales & $\begin{array}{l}-0.0593 \\
(0.0369)\end{array}$ & India*TargetEBITDA & $\begin{array}{c}-0.3182 * * * \\
(0.0755)\end{array}$ \\
\hline Ireland $*$ TargetAssets & $\begin{array}{c}-0.1022 * * \\
(0.0504)\end{array}$ & Ireland $*$ TargetSales & $\begin{array}{c}-0.0565 \\
(0.0410)\end{array}$ & Ireland*TargetEBITDA & $\begin{array}{c}-0.1737 * * \\
(0.0714)\end{array}$ \\
\hline Israel $*$ TargetAssets & $\begin{array}{l}-0.0013 \\
(0.0810)\end{array}$ & Israel*TargetSales & $\begin{array}{c}-0.0859 \\
(0.0572)\end{array}$ & Israel ${ }^{*}$ TargetEBITDA & $\begin{array}{c}0.0781 \\
(0.1288)\end{array}$ \\
\hline Italy $*$ TargetAssets & $\begin{array}{c}0.0162 \\
(0.0585)\end{array}$ & Italy*TargetSales & $\begin{array}{c}0.0067 \\
(0.0457)\end{array}$ & Italy $*$ TargetEBITDA & $\begin{array}{c}0.0309 \\
(0.0794)\end{array}$ \\
\hline Japan $*$ TargetAssets & $\begin{array}{c}0.1112 * * \\
(0.0461)\end{array}$ & Japan $*$ TargetSales & $\begin{array}{c}0.1007 * * \\
(0.0404)\end{array}$ & Japan*TargetEBITDA & $\begin{array}{c}0.0818 \\
(0.0696)\end{array}$ \\
\hline KoreaRep $*$ TargetAssets & $\begin{array}{c}0.0875 \\
(0.1026)\end{array}$ & KoreaRep $*$ TargetSales & $\begin{array}{l}-0.0338 \\
(0.0893)\end{array}$ & KoreaRep $*$ TargetEBITDA & $\begin{array}{c}0.2206 \\
(0.2751)\end{array}$ \\
\hline Malaysia $*$ TargetAssets & $\begin{array}{l}-0.1075 \\
(0.1090)\end{array}$ & Malaysia*TargetSales & $\begin{array}{l}-0.1171^{*} \\
(0.0707)\end{array}$ & Malaysia*TargetEBITDA & $\begin{array}{l}-0.2086 \\
(0.1310)\end{array}$ \\
\hline Netherlands $*$ TargetAssets & $\begin{array}{c}0.1765^{* * *} * \\
(0.0504)\end{array}$ & Netherlands*TargetSales & $\begin{array}{l}0.0893 * \\
(0.0458)\end{array}$ & Netherlands $*$ TargetEBITDA & $\begin{array}{c}0.1696 * * \\
(0.0699)\end{array}$ \\
\hline NewZealand $*$ TargetAssets & $\begin{array}{l}-0.0111 \\
(0.1395)\end{array}$ & NewZealand $*$ TargetSales & $\begin{array}{c}0.2038 * * \\
(0.0951)\end{array}$ & NewZealand $*$ TargetEBITDA & $\begin{array}{l}-0.1343 \\
(0.1243)\end{array}$ \\
\hline Norway*TargetAssets & $\begin{array}{c}-0.2134 * * * \\
(0.0732)\end{array}$ & Norway $*$ TargetSales & $\begin{array}{c}-0.1773 * * * \\
(0.0423)\end{array}$ & Norway*TargetEBITDA & $\begin{array}{c}-0.2307 * * \\
(0.1167)\end{array}$ \\
\hline RussianFederation $*$ TargetAssets & $\begin{array}{c}0.0481 \\
(0.2429)\end{array}$ & RussianFederation*TargetSales & $\begin{array}{l}-0.1325 \\
(0.1597)\end{array}$ & RussianFederation*TargetEBITDA & $\begin{array}{c}0.2715 \\
(0.1787)\end{array}$ \\
\hline Singapore*TargetAssets & $\begin{array}{l}-0.0009 \\
(0.0640)\end{array}$ & Singapore $*$ TargetSales & $\begin{array}{c}-0.0877 \\
(0.0580)\end{array}$ & Singapore*TargetEBITDA & $\begin{array}{l}-0.0784 \\
(0.0812)\end{array}$ \\
\hline Spain $*$ TargetAssets & $\begin{array}{c}0.2229 * * * \\
(0.0759)\end{array}$ & Spain*TargetSales & $\begin{array}{c}0.1261 * * \\
(0.0589)\end{array}$ & Spain*TargetEBITDA & $\begin{array}{c}0.1338 \\
(0.0972)\end{array}$ \\
\hline Sweden*TargetAssets & $\begin{array}{c}0.3177 * * * \\
(0.1215)\end{array}$ & Sweden*TargetSales & $\begin{array}{c}-0.0665 \\
(0.0901)\end{array}$ & Sweden $*$ TargetEBITDA & $\begin{array}{c}0.0543 \\
(0.1561)\end{array}$ \\
\hline Switzerland $*$ TargetAssets & $\begin{array}{c}0.1798 * * * \\
(0.0563)\end{array}$ & Switzerland $*$ TargetSales & $\begin{array}{c}0.0347 \\
(0.0557)\end{array}$ & Switzerland*TargetEBITDA & $\begin{array}{c}0.1748 * * \\
(0.0872)\end{array}$ \\
\hline UnitedKingdom $*$ TargetAssets & $\begin{array}{l}-0.0638 \\
(0.0475)\end{array}$ & UnitedKingdom $*$ TargetSales & $\begin{array}{c}-0.1709 * * * \\
(0.0314)\end{array}$ & UnitedKingdom $*$ TargetEBITDA & $\begin{array}{l}-0.0150 \\
(0.0577)\end{array}$ \\
\hline Australia $*$ TargetROA & $\begin{array}{c}0.0451 \\
(0.1562)\end{array}$ & & & & \\
\hline Austria*TargetROA & $\begin{array}{c}-0.3821 * * \\
(0.1873)\end{array}$ & & & & \\
\hline Belgium $*$ TargetROA & $\begin{array}{c}0.0782 \\
(0.3381)\end{array}$ & & & & \\
\hline Canada*TargetROA & $\begin{array}{c}0.0885 \\
(0.2366)\end{array}$ & & & & \\
\hline China $*$ TargetROA & $\begin{array}{c}-0.3323 * * \\
(0.1653)\end{array}$ & & & & \\
\hline Denmark $*$ TargetROA & $\begin{array}{c}0.3034 \\
(0.2514)\end{array}$ & & & & \\
\hline Finland ${ }^{*}$ TargetROA & $\begin{array}{c}0.4007 * * * \\
(0.1818)\end{array}$ & & & & \\
\hline France $*$ TargetROA & $\begin{array}{c}0.1699 \\
(0.1596)\end{array}$ & & & & \\
\hline Germany*TargetROA & $\begin{array}{c}-0.3493 * * \\
(0.1597)\end{array}$ & & & & \\
\hline HongKongSARChina*TargetROA & $\begin{array}{c}0.0771 \\
(0.1329)\end{array}$ & & & & \\
\hline India $*$ TargetROA & $\begin{array}{c}0.0564 \\
(0.1776)\end{array}$ & & & & \\
\hline Ireland $*$ TargetROA & $\begin{array}{l}0.2417^{*} \\
(0.1374)\end{array}$ & & & & \\
\hline Israel $*$ TargetROA & $\begin{array}{c}-0.3429^{* *} \\
(0.1377)\end{array}$ & & & & \\
\hline Italy*TargetROA & $\begin{array}{l}-0.1279 \\
(0.1952)\end{array}$ & & & & \\
\hline
\end{tabular}




\begin{tabular}{|c|c|}
\hline Japan*TargetROA & $\begin{array}{c}0.4780^{* * * *} \\
(0.1482)\end{array}$ \\
\hline KoreaRep*TargetROA & $\begin{array}{c}-0.3778^{* *} \\
(0.1693)\end{array}$ \\
\hline Malaysia $*$ TargetROA & $\begin{array}{c}0.1243 \\
(0.1701)\end{array}$ \\
\hline Netherlands $*$ TargetROA & $\begin{array}{c}0.3409 \\
(0.2256)\end{array}$ \\
\hline NewZealand ${ }^{*}$ TargetROA & $\begin{array}{c}0.3107 * * \\
(0.1298)\end{array}$ \\
\hline Norway*TargetROA & $\begin{array}{c}-0.0062 \\
(0.1873)\end{array}$ \\
\hline RussianFederation*TargetROA & $\begin{array}{c}0.1880 \\
(0.3663)\end{array}$ \\
\hline Singapore*TargetROA & $\begin{array}{c}-0.2435^{*} \\
(0.1407)\end{array}$ \\
\hline Spain*TargetROA & $\begin{array}{c}0.1719 \\
(0.2793)\end{array}$ \\
\hline Sweden*TargetROA & $\begin{array}{c}7.1903 * * \\
(3.2794)\end{array}$ \\
\hline Switzerland $*$ TargetROA & $\begin{array}{c}-0.2943^{*} \\
(0.1715)\end{array}$ \\
\hline UnitedKingdom*TargetROA & $\begin{array}{c}0.2905^{* *} \\
(0.1420)\end{array}$ \\
\hline
\end{tabular}

Table reports supplemental results of regressions (3), (4) and (5) of Table 6. In particular, the coefficient of the interaction between candidate acquirer country fixed effects with target-specific consolidated financial data (target total assets, target return on assets, target net sales and target earnings before interest, taxes, depreciation and amortization) are shown. In all regressions, the US represent the base category $* * *$, and $* * *$ denote statistical significance at $10 \%, 5 \%$, and $1 \%$ levels, respectively. Robust standard errors are provided in parentheses. 
Table 8. Cross-border M\&A sample (2002-2014) for analyzing effect of acquirer CFC rules on probability of being target country (Section 3.4.2).

\begin{tabular}{|c|c|c|c|c|c|c|c|}
\hline Country & $\begin{array}{l}\text { CFC } \\
\text { rule }\end{array}$ & $\begin{array}{l}\text { Number of } \\
\text { acquirers }\end{array}$ & $\begin{array}{c}\text { Number of } \\
\text { targets }\end{array}$ & Country & $\begin{array}{l}\text { CFC } \\
\text { rule }\end{array}$ & $\begin{array}{l}\text { Number of } \\
\text { acquirers }\end{array}$ & $\begin{array}{c}\text { Number of } \\
\text { targets }\end{array}$ \\
\hline Australia & 1 & 712 & 801 & Japan & 1 & 431 & 170 \\
\hline Austria & 0 & 77 & $\mathrm{n} / \mathrm{a}$ & Korea, Rep. & 1 & 162 & 153 \\
\hline Belarus & 0 & 1 & $\mathrm{n} / \mathrm{a}$ & Lithuania & 1 & 5 & $\mathrm{n} / \mathrm{a}$ \\
\hline Belgium & 0 & 123 & 197 & Malaysia & 0 & 178 & 174 \\
\hline Bermuda & 0 & 56 & $\mathrm{n} / \mathrm{a}$ & Malta & 0 & 5 & $\mathrm{n} / \mathrm{a}$ \\
\hline Brazil & 1 & 40 & 320 & Mexico & 1 & 54 & 270 \\
\hline British Virgin Islands & 0 & 28 & $\mathrm{n} / \mathrm{a}$ & Netherlands & 0 & 296 & 404 \\
\hline Bulgaria & 0 & 1 & $\mathrm{n} / \mathrm{a}$ & New Zealand & 1 & 92 & 141 \\
\hline Canada & 1 & 1,824 & 594 & Norway & 1 & 130 & 260 \\
\hline Cayman Islands & 0 & 17 & $\mathrm{n} / \mathrm{a}$ & Panama & 0 & 5 & $\mathrm{n} / \mathrm{a}$ \\
\hline Chile & 0 & 19 & $\mathrm{n} / \mathrm{a}$ & Poland & 0 & 25 & 170 \\
\hline China & 1 & 271 & 897 & Portugal & 1 & 35 & $\mathrm{n} / \mathrm{a}$ \\
\hline Croatia & 0 & 1 & $\mathrm{n} / \mathrm{a}$ & Russian Federation & 0 & 51 & 82 \\
\hline Cyprus & 0 & 35 & $\mathrm{n} / \mathrm{a}$ & Seychelles & 0 & 7 & $\mathrm{n} / \mathrm{a}$ \\
\hline Czech Republic & 0 & 7 & $\mathrm{n} / \mathrm{a}$ & Singapore & 0 & 416 & 290 \\
\hline Denmark & 1 & 118 & 35 & Slovak Republic & 0 & 2 & $\mathrm{n} / \mathrm{a}$ \\
\hline Estonia & 0 & 1 & $\mathrm{n} / \mathrm{a}$ & Slovenia & 0 & 5 & $\mathrm{n} / \mathrm{a}$ \\
\hline Finland & 1 & 112 & 44 & South Africa & 1 & 58 & 156 \\
\hline France & 1 & 490 & 708 & Spain & 1 & 239 & 369 \\
\hline Germany & 1 & 433 & 951 & Sweden & 1 & 365 & $\mathrm{n} / \mathrm{a}$ \\
\hline Greece & 1 & 17 & $\mathrm{n} / \mathrm{a}$ & Switzerland & 0 & 268 & 240 \\
\hline Hong Kong SAR, China & 0 & 487 & 377 & Taiwan, China & 0 & 90 & $\mathrm{n} / \mathrm{a}$ \\
\hline Hungary & 1 & 7 & $\mathrm{n} / \mathrm{a}$ & Turkey & 1 & 17 & $\mathrm{n} / \mathrm{a}$ \\
\hline Iceland & 1 & 38 & $\mathrm{n} / \mathrm{a}$ & Ukraine & 0 & 8 & $\mathrm{n} / \mathrm{a}$ \\
\hline India & 0 & 295 & 227 & United Kingdom & 1 & 2,023 & 1,084 \\
\hline Ireland & 0 & 253 & 181 & United States & 1 & 2,647 & 3,818 \\
\hline Israel & 1 & 172 & $\mathrm{n} / \mathrm{a}$ & & & & \\
\hline Italy & 1 & 198 & 334 & Total & & 13,447 & 13,447 \\
\hline
\end{tabular}

Table shows number of acquirer ultimate parents and targets per country in our cross-border M\&A sample to investigate Hypothesis 1b. In this context, cross-border M\&As are defined as acquirer ultimate parent and target residing in different countries; the direct acquirer and acquirer ultimate parent reside in the same country. CFC rule takes the value one, if the country has implemented CFC rules in 2014. 


\begin{tabular}{|c|c|c|c|c|c|c|c|}
\hline Variable & Definition & Data source & Obs. & Mean & Std. Dev. & Min & Max \\
\hline$C F C^{\text {dummy }}$ & $\begin{array}{l}\text { Binary dummy variable coded one if target country STR is smaller than acquirer country's tax rate threshold } \\
\text { of CFC rule or acquirer country applies CFC rules without a tax rate threshold, and } 0 \text { otherwise }\end{array}$ & Tax guides & 317,444 & 0.345 & 0.475 & 0 & 1 \\
\hline$C F C^{\text {diff }}$ & $\begin{array}{l}\text { Difference between acquirer country STR and target country STR if target country STR is smaller than } \\
\text { acquirer country's tax rate threshold of CFC rule or acquirer country applies CFC rules without a tax rate } \\
\text { threshold, and } 0 \text { otherwise }\end{array}$ & Tax guides & 317,444 & 0.037 & 0.063 & 0.000 & 0.284 \\
\hline$C F C^{\text {diffEATR }}$ & $\begin{array}{l}\text { Difference between acquirer country STR and target country STR if target country EATR is smaller than } \\
\text { acquirer country's tax rate threshold of the CFC rule or acquirer country applies CFC rules without a tax rate } \\
\text { threshold, and } 0 \text { otherwise }\end{array}$ & $\begin{array}{l}\text { Tax guides; Oxford } \\
\text { University Centre for } \\
\text { Business Taxation }\end{array}$ & 317,444 & 0.031 & 0.057 & -0.033 & 0.284 \\
\hline$C F C^{\text {diffEEA }}$ & $\begin{array}{l}\text { Same as } C F C^{\text {diff }} \text {; however, set to zero if acquirer and target country are both EEA Member States and M\&A } \\
\text { year is after } 2006\end{array}$ & Tax guides & 317,444 & 0.035 & 0.062 & 0.000 & 0.284 \\
\hline Below & See expression (6) & Tax guides & 317,444 & 0.037 & 0.063 & 0.000 & 0.284 \\
\hline Above & See expression (7) & Tax guides & 317,444 & 0.008 & 0.026 & 0.000 & 0.258 \\
\hline Higher & See expression (8) & Tax guides & 317,444 & 0.014 & 0.030 & 0.000 & 0.259 \\
\hline$C F C^{\text {taxbase }}$ & See expression (10) & Tax guides & 317,444 & 0.305 & 0.058 & 0.125 & 0.409 \\
\hline$C F C^{\text {profitable }}$ & Same as $C F C^{\text {diff }}$; however, for non-profitable targets set to zero & $\begin{array}{l}\text { Tax guides; SDC; } \\
\text { Compustat North America; } \\
\text { Compustat Global }\end{array}$ & 53,270 & 0.026 & 0.057 & 0.000 & 0.284 \\
\hline$C F C^{\text {non_profitable }}$ & Same as $C F C^{\text {diff }}$; however, for profitable targets set to zero & $\begin{array}{l}\text { Tax guides; SDC; } \\
\text { Compustat North America; } \\
\text { Compustat Global }\end{array}$ & 53,270 & 0.013 & 0.042 & 0.000 & 0.277 \\
\hline STR & STR in candidate target country, including typical local taxes & Tax guides & 317,444 & 0.287 & 0.071 & 0.125 & 0.409 \\
\hline InGDPpercapita & GDP per capita in candidate target country (natural logarithm) & World Bank & 317,444 & 10.267 & 0.687 & 7.942 & 11.284 \\
\hline GDPgrowth & Growth of GDP in candidate target country (in \%) & World Bank & 317,444 & 3.221 & 3.206 & -7.821 & 15.240 \\
\hline StockmarketSize & Stock market capitalization of listed domestic companies in candidate target country (in \% of GDP) & World Bank & 317,444 & 124.1 & 178.4 & 17.020 & $1,254.9$ \\
\hline PrivateCredit & Domestic credit to private sector in candidate target country (in \% of GDP) & World Bank & 317,444 & 109.5 & 47.091 & 13.353 & 233.4 \\
\hline InDistance & $\begin{array}{l}\text { Simple distance (in } \mathrm{km} \text { ) between most populated cities of acquirer and candidate target country (natural } \\
\text { logarithm) }\end{array}$ & Mayer and Zignago (2011) & 317,444 & 8.609 & 1.046 & 5.153 & 9.883 \\
\hline CommonLanguage & $\begin{array}{l}\text { Common language index between acquirer and candidate target country ( } 0 \text { (low similarity) to } 1 \text { (high } \\
\text { similarity)) }\end{array}$ & Melitz and Toubal (2014) & 317,444 & 0.235 & 0.212 & 0.000 & 0.991 \\
\hline ColonialRelationship & $\begin{array}{l}\text { Binary dummy variable coded one if acquirer and candidate target country were ever in a colonial } \\
\text { relationship, and } 0 \text { otherwise }\end{array}$ & Mayer and Zignago (2011) & 317,444 & 0.103 & 0.304 & 0 & 1 \\
\hline CommonLegalSystem & $\begin{array}{l}\text { Binary dummy variable coded one if legal system of acquirer and candidate target country have common } \\
\text { legal origins, and } 0 \text { otherwise }\end{array}$ & Head et al. (2010) & 317,444 & 0.329 & 0.470 & 0 & 1 \\
\hline Corruption Control & Corruption control index of candidate target country (-3 (low control) to 3 (high control)) & $\mathrm{W}$ & 317,444 & 1.072 & 0.976 & -1.088 & 2.527 \\
\hline BusinessStartupCost & Cost of business start-up procedures in candidate target country (in $\%$ of GNI per capita) & World Bank & 317,444 & 9.601 & 12.746 & 0.000 & 78.400 \\
\hline UnemploymentRate & Unemployment rate in candidate target country (in \% of total labor force) & World Bank & 317,444 & 7.031 & 5.050 & 2.493 & 27.140 \\
\hline InDomesticFirms & Number of listed domestic companies in candidate target country (natural logarithm) & World Bank & 317,444 & 6.426 & 1.232 & 3.714 & 8.638 \\
\hline BusinessDisclosure & Business extent of disclosure index of in candidate target country (0 (less disclosure) to 10 (more disclosure)) & World Bank & 264,159 & 7.188 & 2.344 & 0 & 10 \\
\hline AcquirerAssets & Pre-deal consolidated acquirer total assets in the last year before the effective M\&A date (natural logarithm) & $\begin{array}{l}\text { SDC; Compustat North } \\
\text { America; Compustat Global }\end{array}$ & 215,197 & 20.280 & 2.808 & 11.513 & 28.710 \\
\hline AcquirerROA & $\begin{array}{l}\text { Pre-deal consolidated acquirer pre-tax income in the last year before the effective M\&A date divided by pre- } \\
\text { deal consolidated acquirer total assets in the last year before the effective M\&A date }\end{array}$ & $\begin{array}{l}\text { SDC; Compustat North } \\
\text { America; Compustat Global }\end{array}$ & 215,197 & 0.035 & 5.999 & -191.9 & 360.5 \\
\hline AcquirerSales & Pre-deal consolidated acquirer net sales in the last year before the effective M\&A date (natural logarithm) & $\begin{array}{l}\text { SDC; Compustat North } \\
\text { America; Compustat Global }\end{array}$ & 206,176 & 19.979 & 2.732 & 8.219 & 26.834 \\
\hline AcquirerEBITDA & $\begin{array}{l}\text { Pre-deal consolidated acquirer EBITDA (earnings before interest, taxes, depreciation and amortization) in the } \\
\text { last year before the effective M\&A date (natural logarithm) }\end{array}$ & $\begin{array}{l}\text { SDC; Compustat North } \\
\text { America; Compustat Global }\end{array}$ & 180,202 & 18.594 & 2.365 & 9.210 & 24.723 \\
\hline
\end{tabular}

Data on country fixed effects are not reported but are available upon request. 
Table 10. Effect of acquirer CFC rules on probability of being target country (Section 3.4.2).

\begin{tabular}{|c|c|c|c|c|c|}
\hline Explanatory variables & $\begin{array}{c}(1) \\
\text { Conditional logit }\end{array}$ & $\begin{array}{c}(2) \\
\text { Conditional logit }\end{array}$ & $\begin{array}{c}(3) \\
\text { Mixed logit }\end{array}$ & $\begin{array}{c}(4) \\
\text { Mixed logit }\end{array}$ & $\begin{array}{c}(5) \\
\text { Mixed logit }\end{array}$ \\
\hline$C F C^{\text {dummy }}$ & $\begin{array}{c}-0.1078 * * \\
(0.0450)\end{array}$ & & & & \\
\hline$C F C^{\text {diff }}$ & & $\begin{array}{c}-1.7115^{* * * *} \\
(0.3921)\end{array}$ & $\begin{array}{c}-2.8880 * * * \\
(0.5306)\end{array}$ & $\begin{array}{c}-2.8880 * * * \\
(0.8075)\end{array}$ & \\
\hline Below & & & & & $\begin{array}{c}-4.7124 * * * \\
(0.5975)\end{array}$ \\
\hline Above & & & & & $\begin{array}{c}-8.6127 * * * \\
(1.0042)\end{array}$ \\
\hline Higher & & & & & $\begin{array}{c}-1.1460 * * \\
(0.5413)\end{array}$ \\
\hline STR & $\begin{array}{c}2.6019 * * * \\
(0.6293)\end{array}$ & $\begin{array}{c}2.4139 * * * \\
(0.6309)\end{array}$ & $\begin{array}{c}2.0753 * * * \\
(0.6398)\end{array}$ & $\begin{array}{c}2.0753 * * \\
(0.8535)\end{array}$ & $\begin{array}{l}1.6429 * * \\
(0.6891)\end{array}$ \\
\hline InGDPpercapita & $\begin{array}{l}-0.0639 \\
(0.1740)\end{array}$ & $\begin{array}{l}-0.0388 \\
(0.1739)\end{array}$ & $\begin{array}{l}-0.0848 \\
(0.1744)\end{array}$ & $\begin{array}{l}-0.0848 \\
(0.3059)\end{array}$ & $\begin{array}{l}-0.1192 \\
(0.1788)\end{array}$ \\
\hline GDPgrowth & $\begin{array}{l}0.0142 * \\
(0.0081)\end{array}$ & $\begin{array}{l}0.0143 * \\
(0.0081)\end{array}$ & $\begin{array}{l}0.0134 * \\
(0.0081)\end{array}$ & $\begin{array}{c}0.0134 \\
(0.0112)\end{array}$ & $\begin{array}{c}0.0128 \\
(0.0082)\end{array}$ \\
\hline StockmarketSize & $\begin{array}{l}-0.0003 \\
(0.0002)\end{array}$ & $\begin{array}{l}-0.0003 \\
(0.0002)\end{array}$ & $\begin{array}{l}-0.0003 \\
(0.0002)\end{array}$ & $\begin{array}{l}-0.0003 \\
(0.0003)\end{array}$ & $\begin{array}{l}-0.0003 \\
(0.0002)\end{array}$ \\
\hline PrivateCredit & $\begin{array}{c}-0.0019 * * \\
(0.0008)\end{array}$ & $\begin{array}{c}-0.0019 * * \\
(0.0008)\end{array}$ & $\begin{array}{c}-0.0021 * * * \\
(0.0008)\end{array}$ & $\begin{array}{c}-0.0021 * * \\
(0.0011)\end{array}$ & $\begin{array}{c}-0.0022 * * * \\
(0.0008)\end{array}$ \\
\hline InDistance & $\begin{array}{c}-0.5799 * * * \\
(0.0112)\end{array}$ & $\begin{array}{c}-0.5740 * * * \\
(0.0114)\end{array}$ & $\begin{array}{c}-0.5736 * * * \\
(0.0114)\end{array}$ & $\begin{array}{c}-0.5736 * * * \\
(0.0188)\end{array}$ & $\begin{array}{c}-0.5934 * * * \\
(0.0123)\end{array}$ \\
\hline CommonLanguage & $\begin{array}{l}1.9043 * * * \\
(0.0639)\end{array}$ & $\begin{array}{l}1.9006 * * * \\
(0.0638)\end{array}$ & $\begin{array}{c}1.9162 * * * \\
(0.0641)\end{array}$ & $\begin{array}{c}1.9162 * * * \\
(0.1225)\end{array}$ & $\begin{array}{c}1.9734 * * * \\
(0.0671)\end{array}$ \\
\hline ColonialRelationship & $\begin{array}{c}0.2992 * * * \\
(0.0375)\end{array}$ & $\begin{array}{c}0.2777 * * * \\
(0.0377)\end{array}$ & $\begin{array}{c}0.2712 * * * \\
(0.0378)\end{array}$ & $\begin{array}{c}0.2712 * * * \\
(0.0489)\end{array}$ & $\begin{array}{c}0.2252 * * * \\
(0.0387)\end{array}$ \\
\hline CommonLegalSystem & $\begin{array}{c}0.0172 \\
(0.0269)\end{array}$ & $\begin{array}{c}0.0311 \\
(0.0271)\end{array}$ & $\begin{array}{c}0.0345 \\
(0.0272)\end{array}$ & $\begin{array}{c}0.0345 \\
(0.0483)\end{array}$ & $\begin{array}{l}0.0672 * * \\
(0.0278)\end{array}$ \\
\hline CorruptionControl & $\begin{array}{l}0.1651^{*} \\
(0.0859)\end{array}$ & $\begin{array}{l}0.1644 * \\
(0.0860)\end{array}$ & $\begin{array}{l}0.1600 * \\
(0.0863)\end{array}$ & $\begin{array}{c}0.1600 \\
(0.1337)\end{array}$ & $\begin{array}{l}0.1542 * \\
(0.0884)\end{array}$ \\
\hline BusinessStartupCost & $\begin{array}{c}-0.0073 * * \\
(0.0033)\end{array}$ & $\begin{array}{c}-0.0072 * * \\
(0.0033)\end{array}$ & $\begin{array}{c}-0.0075 * * \\
(0.0033)\end{array}$ & $\begin{array}{l}-0.0075^{*} \\
(0.0044)\end{array}$ & $\begin{array}{c}-0.0069 * * \\
(0.0033)\end{array}$ \\
\hline UnemploymentRate & $\begin{array}{l}-0.0004 \\
(0.0064)\end{array}$ & $\begin{array}{c}0.0001 \\
(0.0064)\end{array}$ & $\begin{array}{c}0.0004 \\
(0.0064)\end{array}$ & $\begin{array}{c}0.0004 \\
(0.0085)\end{array}$ & $\begin{array}{l}-0.0002 \\
(0.0065)\end{array}$ \\
\hline lnDomesticFirms & $\begin{array}{c}0.1775^{* *} \\
(0.0848)\end{array}$ & $\begin{array}{l}0.1651 * \\
(0.0846)\end{array}$ & $\begin{array}{l}0.1834 * * \\
(0.0848)\end{array}$ & $\begin{array}{c}0.1834 \\
(0.1338)\end{array}$ & $\begin{array}{c}0.2095 * * \\
(0.0853)\end{array}$ \\
\hline Target country fixed effects & YES & YES & YES & YES & YES \\
\hline Observations & 317,444 & 317,444 & 317,444 & 317,444 & 317,444 \\
\hline Log-likelihood & $-31,158$ & $-31,151$ & $-31,144$ & $-31,144$ & $-31,064$ \\
\hline
\end{tabular}

Regressions of probability of being the target country on (potential) CFC rule application in acquirer country; see expression (3). For each deal, the dependent variable equals one if country $i$ is the actual target's country of origin, and zero if country $i$ is a counterfactual target country. For variable definitions and data sources, see Table 9. Only crossborder M\&As where the direct acquirer country is equal to the acquirer ultimate parent country are considered. All regressions control for target country fixed effects, which are available upon request. The variables of interest follow a random distribution in the mixed logit regressions. Regressions (1) and (2) are estimated by a conditional logit model and regressions (3), (4) and (5) are estimated by a mixed logit model. Regression (4) is identical to regression (3) except for standard errors, which are robust to clustering on the acquirer-country-year level. *, **, and *** denote statistical significance at $10 \%, 5 \%$, and $1 \%$ levels, respectively. Robust standard errors are provided in parentheses. 
Table 11. Robustness tests of effect of acquirer CFC rules on probability of being target country (Section 3.4.2).

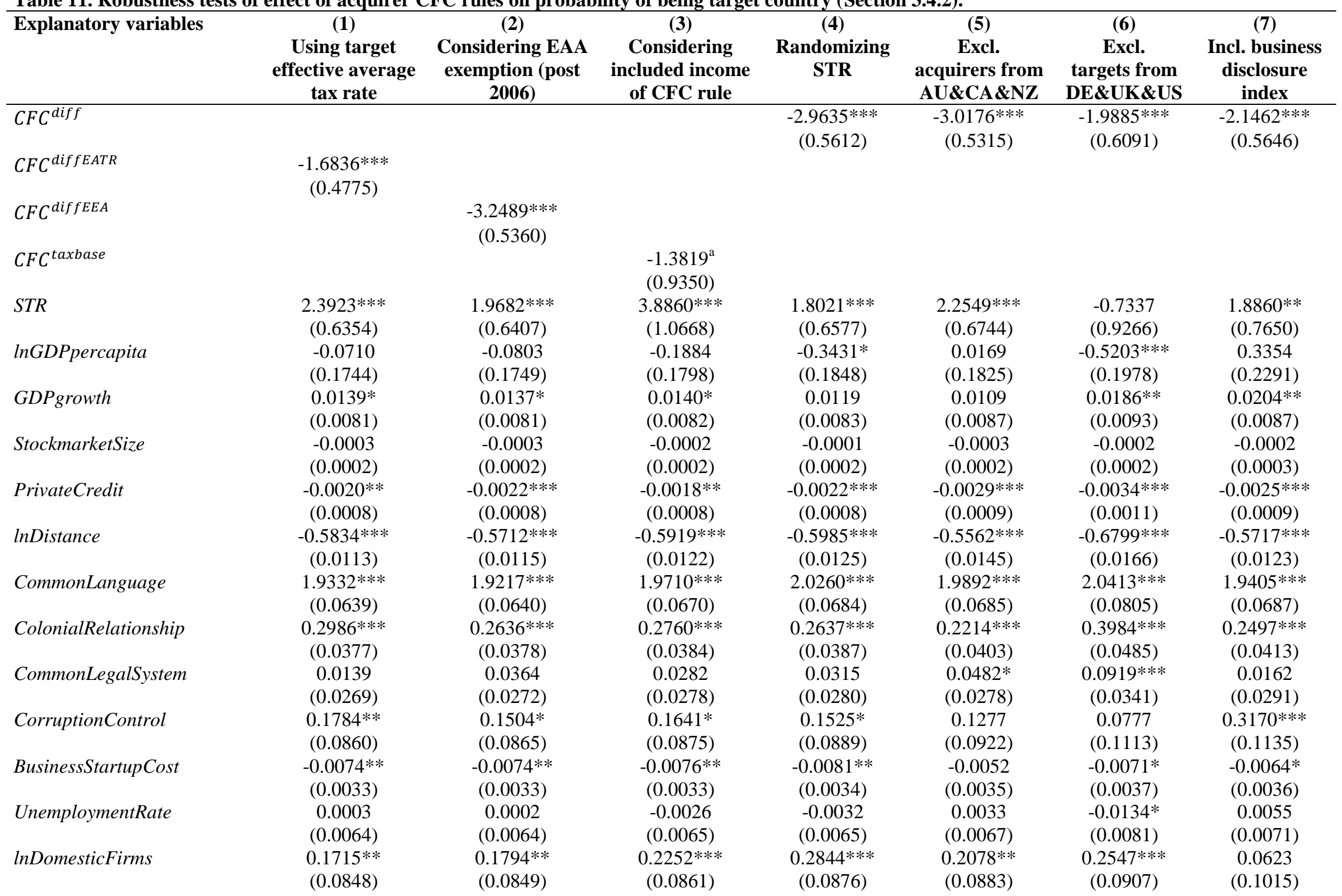


BusinessDisclosure

0.0820

Target country fixed effects

317,444

Observations

Log-likelihood

$-31,155$

17,444

317,444

317,444

$-31,136$

$-31,119$

Regressions of probability of being the target country on (potential) CFC rule application in acquirer country; see expression (3). For each deal, the dependent

variable equals one if country $i$ is the actual target's country of origin, and zero if country $i$ is a counterfactual target country. For variable definitions and data sources, see Table 9. Only cross-border M\&As where the direct acquirer country is equal to the acquirer ultimate parent country are considered. All regressions control for target country fixed effects, which are available upon request, and are estimated by a mixed logit model. The variables of interest follow a random distribution in the mixed logit regressions. Regression (1), (2) and (3) check whether our variable of interest is robust to using effective average tax rates, considering potential non-application of CFC rules within the EEA and considering the included income by CFC rules. In regression (4), also STR follows a random distribution. Regressions (5) and (6) exclude certain countries and regression (7) considers a further control variable (BusinessDisclosure). *,**, and *** denote statistical significance at $10 \%, 5 \%$, and $1 \%$ levels, respectively. Robust standard errors are provided in parentheses.

${ }^{\mathrm{a}}$ The level of statistical significance is $13.9 \%$. 
Table 12. Further robustness tests of effect of acquirer CFC rules on probability of being target country (Section 3.4.2).

\begin{tabular}{|c|c|c|c|c|c|}
\hline Explanatory variables & $\begin{array}{c}(1) \\
\text { Excl. } \\
\text { control } \\
\text { variables }\end{array}$ & $\begin{array}{c}\text { (2) } \\
\text { Profitable vs. non- } \\
\text { profitable targets }\end{array}$ & $\begin{array}{c}\text { (3) } \\
\text { Incl. acquirer } \\
\text { assets \& acquirer } \\
\text { return on assets }\end{array}$ & $\begin{array}{c}\text { (4) } \\
\text { Incl. acquirer } \\
\text { sales }\end{array}$ & $\begin{array}{c}\text { (5) } \\
\text { Incl. acquirer } \\
\text { EBITDA }\end{array}$ \\
\hline$C F C^{\text {diff }}$ & $\begin{array}{c}-6.4155^{* * *} * \\
(0.4292)\end{array}$ & & $\begin{array}{c}-3.5409 * * * \\
(0.6830)\end{array}$ & $\begin{array}{c}-3.4268 * * * \\
(0.6655)\end{array}$ & $\begin{array}{c}-3.2957 * * * \\
(0.7050)\end{array}$ \\
\hline$C F C^{\text {profitable }}$ & & $\begin{array}{c}-6.4673^{* * *} * \\
(1.6700)\end{array}$ & & & \\
\hline CFC $C^{\text {non_profitable }}$ & & $\begin{array}{c}-7.2323 * * * \\
(1.9287)\end{array}$ & & & \\
\hline$S T R$ & & $\begin{array}{l}-1.8795 \\
(1.7514)\end{array}$ & $\begin{array}{c}2.4216 * * * \\
(0.7889)\end{array}$ & $\begin{array}{c}2.7097 * * * \\
(0.7979)\end{array}$ & $\begin{array}{c}2.7031 * * * \\
(0.8450)\end{array}$ \\
\hline InGDPpercapita & & $\begin{array}{c}0.2851 \\
(0.5944)\end{array}$ & $\begin{array}{c}-0.1952 \\
(0.2289)\end{array}$ & $\begin{array}{l}-0.0804 \\
(0.2319)\end{array}$ & $\begin{array}{l}-0.3150 \\
(0.2494)\end{array}$ \\
\hline GDPgrowth & & $\begin{array}{l}-0.0329 \\
(0.0227)\end{array}$ & $\begin{array}{c}0.0119 \\
(0.0101)\end{array}$ & $\begin{array}{c}0.0107 \\
(0.0104)\end{array}$ & $\begin{array}{c}0.0096 \\
(0.0111)\end{array}$ \\
\hline StockmarketSize & & $\begin{array}{l}-0.0003 \\
(0.0007)\end{array}$ & $\begin{array}{c}0.0000 \\
(0.0003)\end{array}$ & $\begin{array}{l}-0.0002 \\
(0.0003)\end{array}$ & $\begin{array}{l}-0.0000 \\
(0.0003)\end{array}$ \\
\hline PrivateCredit & & $\begin{array}{c}-0.0050 * * * \\
(0.0018)\end{array}$ & $\begin{array}{c}-0.0027 * * * \\
(0.0010)\end{array}$ & $\begin{array}{c}-0.0029 * * * \\
(0.0010)\end{array}$ & $\begin{array}{c}-0.0026 * * \\
(0.0011)\end{array}$ \\
\hline InDistance & & $\begin{array}{c}-0.4524 * * * \\
(0.0303)\end{array}$ & $\begin{array}{c}-0.5450 * * * \\
(0.0145)\end{array}$ & $\begin{array}{c}-0.5504 * * * \\
(0.0152)\end{array}$ & $\begin{array}{c}-0.5388 * * * \\
(0.0162)\end{array}$ \\
\hline CommonLanguage & & $\begin{array}{c}2.0888 * * * \\
(0.1776)\end{array}$ & $\begin{array}{c}1.6471 * * * \\
(0.0896)\end{array}$ & $\begin{array}{c}1.5955 * * * \\
(0.0895)\end{array}$ & $\begin{array}{c}1.4247 * * * \\
(0.1006)\end{array}$ \\
\hline ColonialRelationship & & $\begin{array}{c}0.2331 * * * \\
(0.0901)\end{array}$ & $\begin{array}{c}0.2761 * * * \\
(0.0462)\end{array}$ & $\begin{array}{c}0.2821 * * * \\
(0.0468)\end{array}$ & $\begin{array}{c}0.2991 * * * \\
(0.0489)\end{array}$ \\
\hline CommonLegalSystem & & $\begin{array}{c}0.1076 \\
(0.0681)\end{array}$ & $\begin{array}{c}0.1376 * * * \\
(0.0363)\end{array}$ & $\begin{array}{c}0.1668 * * * \\
(0.0363)\end{array}$ & $\begin{array}{c}0.2000 * * * \\
(0.0388)\end{array}$ \\
\hline CorruptionControl & & $\begin{array}{c}0.0070 \\
(0.2145)\end{array}$ & $\begin{array}{c}0.1240 \\
(0.1076)\end{array}$ & $\begin{array}{c}0.0248 \\
(0.1088)\end{array}$ & $\begin{array}{c}0.0192 \\
(0.1168)\end{array}$ \\
\hline BusinessStartupCost & & $\begin{array}{l}-0.0087 \\
(0.0089)\end{array}$ & $\begin{array}{c}-0.0122 * * * \\
(0.0041)\end{array}$ & $\begin{array}{c}-0.0110 * * * \\
(0.0042)\end{array}$ & $\begin{array}{c}-0.0091 * * \\
(0.0046)\end{array}$ \\
\hline UnemploymentRate & & $\begin{array}{l}-0.0252 \\
(0.0160)\end{array}$ & $\begin{array}{l}-0.0091 \\
(0.0081)\end{array}$ & $\begin{array}{l}-0.0124 \\
(0.0082)\end{array}$ & $\begin{array}{l}-0.0128 \\
(0.0087)\end{array}$ \\
\hline lnDomesticFirms & & $\begin{array}{l}0.4353 * \\
(0.2224)\end{array}$ & $\begin{array}{c}0.1074 \\
(0.1060)\end{array}$ & $\begin{array}{c}0.0945 \\
(0.1069)\end{array}$ & $\begin{array}{c}0.1462 \\
(0.1119)\end{array}$ \\
\hline Target country fixed effects & YES & YES & YES & YES & YES \\
\hline Observations & 317,444 & 53,270 & 215,197 & 206,176 & 180,202 \\
\hline Log-likelihood & $-34,219$ & $-5,028$ & $-20,617$ & $-19,818$ & $-17,463$ \\
\hline
\end{tabular}

Regressions of probability of being the target country on (potential) CFC rule application in acquirer country; see expression (3). For each deal, the dependent variable equals one if country $i$ is the actual target's country of origin, and zero if country $i$ is a counterfactual target country. For variable definitions and data sources, see Table 9. Only cross-border M\&As where the direct acquirer country is equal to the acquirer ultimate parent country are considered. All regressions control for target country fixed effects, which are available upon request, and are estimated by a mixed logit model. The variables of interest follow a random distribution in the mixed logit regressions. Regression (1) drops all control variables and regression (2) distinguishes between profitable and non-profitable targets. Regression (3) includes the interaction between target country fixed effects and AcquirerAssets and the interaction between target country fixed effects and AcquirerROA. Regression (4) includes the interaction between target country fixed effects and AcquirerSales. Regression (5) includes the interaction between target country fixed effects and AcquirerEBITDA. The coefficients and standard errors of these interactions are shown in Table 13. *, $* *$, and *** denote statistical significance at $10 \%, 5 \%$, and $1 \%$ levels, respectively. Robust standard errors are provided in parentheses. 
Table 13. Supplemental regression results for candidate target country fixed effects interacted with acquirer-specific financial data.

\begin{tabular}{|c|c|c|c|c|c|}
\hline \multicolumn{2}{|l|}{ Regression (3) of Table 12} & \multicolumn{2}{|l|}{ Regression (4) of Table 12} & \multicolumn{2}{|l|}{ Regression (5) of Table 12} \\
\hline Australia*AcquirerAssets & $\begin{array}{c}-0.0867 * * * \\
(0.0194)\end{array}$ & Australia*AcquirerSales & $\begin{array}{c}-0.0542 * * * \\
(0.0199)\end{array}$ & Australia*AcquirerEBITDA & $\begin{array}{c}-0.0819 * * * \\
(0.0230)\end{array}$ \\
\hline Belgium *AcquirerAssets & $\begin{array}{c}-0.0737 * * \\
(0.0302)\end{array}$ & Belgium*AcquirerSales & $\begin{array}{c}-0.0633 * * \\
(0.0301)\end{array}$ & Belgium*AcquirerEBITDA & $\begin{array}{c}-0.1133 * * * \\
(0.0389)\end{array}$ \\
\hline Brazil $^{*}$ AcquirerAssets & $\begin{array}{c}0.0321 \\
(0.0301)\end{array}$ & Brazil*AcquirerSales & $\begin{array}{c}0.1174 * * * \\
(0.0373)\end{array}$ & Brazil $*$ AcquirerEBITDA & $\begin{array}{c}0.1288^{* * *} \\
(0.0361)\end{array}$ \\
\hline Canada*AcquirerAssets & $\begin{array}{c}-0.1900 * * * \\
(0.0244)\end{array}$ & Canada*AcquirerSales & $\begin{array}{c}-0.1707 * * * \\
(0.0245)\end{array}$ & Canada*AcquirerEBITDA & $\begin{array}{c}-0.1391 * * * \\
(0.0298)\end{array}$ \\
\hline China $*^{*}$ AcquirerAssets & $\begin{array}{c}-0.1894 * * * \\
(0.0212)\end{array}$ & China ${ }^{*}$ AcquirerSales & $\begin{array}{c}-0.1697 * * * \\
(0.0201)\end{array}$ & China $*$ AcquirerEBITDA & $\begin{array}{c}-0.1784 * * * \\
(0.0279)\end{array}$ \\
\hline Denmark $*$ AcquirerAssets & $\begin{array}{l}-0.0393 \\
(0.0754)\end{array}$ & Denmark*AcquirerSales & $\begin{array}{c}-0.0148 \\
(0.0855)\end{array}$ & Denmark*AcquirerEBITDA & $\begin{array}{c}-0.0599 \\
(0.0968)\end{array}$ \\
\hline Finland $*$ AcquirerAssets & $\begin{array}{c}-0.0406 \\
(0.0725)\end{array}$ & Finland $*$ AcquirerSales & $\begin{array}{c}0.0486 \\
(0.0660)\end{array}$ & Finland ${ }^{*}$ AcquirerEBITDA & $\begin{array}{c}-0.1441 \\
(0.1023)\end{array}$ \\
\hline France $*$ AcquirerAssets & $\begin{array}{c}-0.0699 * * * \\
(0.0168)\end{array}$ & France*AcquirerSales & $\begin{array}{c}-0.0638 * * * \\
(0.0174)\end{array}$ & France $*$ AcquirerEBITDA & $\begin{array}{c}-0.1531 * * * \\
(0.0216)\end{array}$ \\
\hline Germany*AcquirerAssets & $\begin{array}{c}-0.0929 * * * \\
(0.0156)\end{array}$ & Germany*AcquirerSales & $\begin{array}{c}-0.0944 * * * \\
(0.0160)\end{array}$ & Germany*AcquirerEBITDA & $\begin{array}{c}-0.1481 * * * \\
(0.0196)\end{array}$ \\
\hline HongKongSARChina*AcquirerAssets & $\begin{array}{c}-0.2496 * * * \\
(0.0345)\end{array}$ & HongKongSARChina*AcquirerSales & $\begin{array}{c}-0.2166 * * * \\
(0.0277)\end{array}$ & HongKongSARChina*AcquirerEBITDA & $\begin{array}{c}-0.2576 * * * \\
(0.0399)\end{array}$ \\
\hline India $*$ AcquirerAssets & $\begin{array}{c}0.0178 \\
(0.0334)\end{array}$ & India*AcquirerSales & $\begin{array}{l}0.0684 * \\
(0.0371)\end{array}$ & India*AcquirerEBITDA & $\begin{array}{c}0.0444 \\
(0.0420)\end{array}$ \\
\hline Ireland ${ }^{*}$ AcquirerAssets & $\begin{array}{c}-0.0215 \\
(0.0349)\end{array}$ & Ireland $*$ AcquirerSales & $\begin{array}{l}-0.0067 \\
(0.0344)\end{array}$ & Ireland ${ }^{*}$ AcquirerEBITDA & $\begin{array}{l}-0.0489 \\
(0.0421)\end{array}$ \\
\hline Italy $*$ AcquirerAssets & $\begin{array}{c}0.0233 \\
(0.0291)\end{array}$ & Italy*AcquirerSales & $\begin{array}{c}0.0241 \\
(0.0300)\end{array}$ & Italy*AcquirerEBITDA & $\begin{array}{c}-0.0159 \\
(0.0359)\end{array}$ \\
\hline Japan*AcquirerAssets & $\begin{array}{c}0.0125 \\
(0.0403)\end{array}$ & Japan $*$ AcquirerSales & $\begin{array}{l}-0.0390 \\
(0.0456)\end{array}$ & Japan*AcquirerEBITDA & $\begin{array}{l}-0.0462 \\
(0.0554)\end{array}$ \\
\hline KoreaRep*AcquirerAssets & $\begin{array}{c}0.0294 \\
(0.0504)\end{array}$ & KoreaRep ${ }^{*}$ AcquirerSales & $\begin{array}{c}0.0095 \\
(0.0494)\end{array}$ & KoreaRep*AcquirerEBITDA & $\begin{array}{c}0.0552 \\
(0.0542)\end{array}$ \\
\hline Malaysia*AcquirerAssets & $\begin{array}{c}-0.2115 * * * \\
(0.0426)\end{array}$ & Malaysia*AcquirerSales & $\begin{array}{c}-0.1429 * * * \\
(0.0421)\end{array}$ & Malaysia*AcquirerEBITDA & $\begin{array}{c}-0.2109 * * * \\
(0.0558)\end{array}$ \\
\hline Mexico*AcquirerAssets & $\begin{array}{c}-0.3658 * * * \\
(0.0316)\end{array}$ & Mexico*AcquirerSales & $\begin{array}{c}-0.1508 * * * \\
(0.0437)\end{array}$ & Mexico*AcquirerEBITDA & $\begin{array}{l}-0.0526 \\
(0.0550)\end{array}$ \\
\hline Netherlands $*$ AcquirerAssets & $\begin{array}{c}-0.0799 * * * \\
(0.0209)\end{array}$ & Netherlands*AcquirerSales & $\begin{array}{c}-0.0567 * * * \\
(0.0215)\end{array}$ & Netherlands *AcquirerEBITDA & $\begin{array}{c}-0.1291 * * * \\
(0.0259)\end{array}$ \\
\hline NewZealand ${ }^{*}$ AcquirerAssets & $\begin{array}{c}-0.1727 * * * \\
(0.0307)\end{array}$ & NewZealand $*$ AcquirerSales & $\begin{array}{c}-0.1197 * * * \\
(0.0266)\end{array}$ & NewZealand $*$ AcquirerEBITDA & $\begin{array}{c}-0.3288 * * * \\
(0.0381)\end{array}$ \\
\hline Norway*AcquirerAssets & $\begin{array}{c}-0.1155 * * * \\
(0.0273)\end{array}$ & Norway*AcquirerSales & $\begin{array}{c}-0.0915 * * * \\
(0.0262)\end{array}$ & Norway*AcquirerEBITDA & $\begin{array}{c}-0.1021 * * * \\
(0.0340)\end{array}$ \\
\hline Poland $*$ AcquirerAssets & $\begin{array}{c}-0.0356 \\
(0.0452)\end{array}$ & Poland $*$ AcquirerSales & $\begin{array}{c}-0.0602 \\
(0.0441)\end{array}$ & Poland $*$ AcquirerEBITDA & $\begin{array}{l}-0.0928^{*} \\
(0.0500)\end{array}$ \\
\hline RussianFederation*AcquirerAssets & $\begin{array}{l}-0.0841 \\
(0.0558)\end{array}$ & RussianFederation*AcquirerSales & $\begin{array}{c}-0.1421 * * \\
(0.0607)\end{array}$ & RussianFederation $*$ AcquirerEBITDA & $\begin{array}{l}-0.0242 \\
(0.0884)\end{array}$ \\
\hline Singapore*AcquirerAssets & $\begin{array}{c}-0.1589 * * * \\
(0.0315)\end{array}$ & Singapore $*$ AcquirerSales & $\begin{array}{c}-0.1096 * * * \\
(0.0268)\end{array}$ & Singapore $*$ AcquirerEBITDA & $\begin{array}{c}-0.1836 * * * \\
(0.0356)\end{array}$ \\
\hline SouthAfrica*AcquirerAssets & $\begin{array}{c}-0.1952 * * * \\
(0.0376)\end{array}$ & SouthAfrica*AcquirerSales & $\begin{array}{c}-0.1524 * * * \\
(0.0371)\end{array}$ & SouthAfrica*AcquirerEBITDA & $\begin{array}{c}-0.1421 * * * \\
(0.0543)\end{array}$ \\
\hline Spain*AcquirerAssets & $\begin{array}{l}-0.0371 \\
(0.0317)\end{array}$ & Spain*AcquirerSales & $\begin{array}{l}-0.0328 \\
(0.0312)\end{array}$ & Spain $*$ AcquirerEBITDA & $\begin{array}{l}-0.0454 \\
(0.0358)\end{array}$ \\
\hline Switzerland $*$ AcquirerAssets & $\begin{array}{c}-0.0841 * * * \\
(0.0264)\end{array}$ & Switzerland $*$ AcquirerSales & $\begin{array}{c}-0.0741 * * * \\
(0.0285)\end{array}$ & Switzerland $*$ AcquirerEBITDA & $\begin{array}{l}-0.0619^{*} \\
(0.0350)\end{array}$ \\
\hline UnitedKingdom $*$ AcquirerAssets & $\begin{array}{c}-0.0884 * * * \\
(0.0174)\end{array}$ & UnitedKingdom $*$ AcquirerSales & $\begin{array}{c}-0.0762 * * * \\
(0.0179)\end{array}$ & UnitedKingdom $*$ AcquirerEBITDA & $\begin{array}{c}-0.1113 * * * \\
(0.0214)\end{array}$ \\
\hline Australia*AcquirerROA & $\begin{array}{l}-0.0370 \\
(0.0295)\end{array}$ & & & & \\
\hline Belgium $*$ AcquirerROA & $\begin{array}{c}0.0158 * * * \\
(0.0057)\end{array}$ & & & & \\
\hline 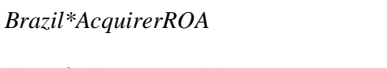 & $\begin{array}{c}-0.0375 \\
(0.0277)\end{array}$ & & & & \\
\hline Canada*AcquirerROA & $\begin{array}{c}-0.0413 \\
(0.0390)\end{array}$ & & & & \\
\hline China*AcquirerROA & $\begin{array}{l}-0.0043 \\
(0.0112)\end{array}$ & & & & \\
\hline Denmark*AcquirerROA & $\begin{array}{c}0.0424 \\
(0.5075)\end{array}$ & & & & \\
\hline Finland $*$ AcquirerROA & $\begin{array}{l}-0.1937 \\
(0.1496)\end{array}$ & & & & \\
\hline France $*$ AcquirerROA & $\begin{array}{c}0.0021 \\
(0.0058)\end{array}$ & & & & \\
\hline Germany $*$ AcquirerROA & $\begin{array}{c}0.0108 * * \\
(0.0053)\end{array}$ & & & & \\
\hline HongKongSARChina $*$ AcquirerROA & $\begin{array}{l}-0.0648 * \\
(0.0355)\end{array}$ & & & & \\
\hline India $*$ AcquirerROA & $\begin{array}{c}-0.0484 \\
(0.0374)\end{array}$ & & & & \\
\hline Ireland ${ }^{*}$ AcquirerROA & $\begin{array}{l}-0.0134 \\
(0.0453)\end{array}$ & & & & \\
\hline Italy $*$ AcquirerROA & $\begin{array}{l}-0.0068 \\
(0.0254)\end{array}$ & & & & \\
\hline Japan*AcquirerROA & $-0.0642 *$ & & & & \\
\hline
\end{tabular}




\begin{tabular}{lc} 
& $(0.0346)$ \\
KoreaRep $*$ AcquirerROA & $-0.0577 *$ \\
& $(0.0337)$ \\
Malaysia*AcquirerROA & 0.0007 \\
& $(0.0079)$ \\
Mexico $*$ AcquirerROA & -0.0010 \\
& $(0.0081)$ \\
Netherlands $*$ AcquirerROA & -0.0154 \\
& $(0.0531)$ \\
NewZealand $*$ AcquirerROA & 0.0195 \\
Norway*AcquirerROA & $(0.0137)$ \\
& -0.0151 \\
Poland $*$ AcquirerROA & $(0.0344)$ \\
& -0.0394 \\
RussianFederation $*$ AcquirerROA & $(0.0410)$ \\
& $-0.0564 *$ \\
Singapore $*$ AcquirerROA & $(0.0339)$ \\
& -0.0539 \\
SouthAfrica $*$ AcquirerROA & $(0.0349)$ \\
Spain $*$ AcquirerROA & 0.0006 \\
& $(0.0076)$ \\
Switzerland $*$ AcquirerROA & -0.0365 \\
& $(0.0386)$ \\
UnitedKingdom $*$ AcquirerROA & 0.0027 \\
& $(0.0058)$ \\
\hline Table repors supplem & -0.0098 \\
& $(0.0196)$
\end{tabular}

Table reports supplemental results of regressions (3), (4) and (5) of Table 12. In particular, the coefficient of the interaction between candidate target country fixed effects with acquirer-specific consolidated financial data (acquirer total assets, acquirer return on assets, acquirer net sales and acquirer earnings before interest, taxes, depreciation and amortization) are shown. In all regressions, the US represent the base category *, **, and *** denote statistical significance at $10 \%, 5 \%$, and $1 \%$ levels, respectively. Robust standard errors are provided in parentheses. 
Table 14. Cross-border M\&A sample (2002-2014) for analyzing effect of CFC rules on direction of cross-border M\&As (Section 4.4).

\begin{tabular}{lccclccc}
\hline Country & $\begin{array}{c}\text { CFC } \\
\text { rule }\end{array}$ & $\begin{array}{c}\text { Number of } \\
\text { acquirers }\end{array}$ & $\begin{array}{c}\text { Number of } \\
\text { targets }\end{array}$ & Country & $\begin{array}{c}\text { CFC } \\
\text { rule }\end{array}$ & $\begin{array}{c}\text { Number of } \\
\text { acquirers }\end{array}$ & $\begin{array}{c}\text { Number of } \\
\text { targets }\end{array}$ \\
\hline Australia & 1 & 43 & 57 & Luxembourg & 0 & 3 & 6 \\
Austria & 0 & 7 & 3 & Mexico & 1 & 7 & 5 \\
Belgium & 0 & 21 & 27 & Netherlands & 0 & 41 & 19 \\
Brazil & 1 & 3 & 24 & New Zealand & 1 & 4 & 4 \\
Canada & 1 & 70 & 101 & Norway & 1 & 9 & 24 \\
Chile & 0 & 2 & 6 & Poland & 0 & 1 & 5 \\
China & 1 & 14 & 6 & Portugal & 1 & 2 & 1 \\
Denmark & 1 & 7 & 9 & Russian Federation & 0 & 6 & 2 \\
France & 1 & 64 & 83 & South Africa & 1 & 20 & 10 \\
Germany & 1 & 55 & 65 & Spain & 1 & 29 & 40 \\
India & 0 & 32 & 12 & Sweden & 1 & 5 & 5 \\
Ireland & 0 & 32 & 14 & Switzerland & 0 & 40 & 18 \\
Israel & 1 & 21 & 16 & United Kingdom & 1 & 156 & 338 \\
Italy & 1 & 30 & 21 & United States & 1 & 411 & 260 \\
Japan & 1 & 55 & 9 & & & & $\mathbf{1 0 9}$ \\
Korea, Rep. & 1 & 9 & 9 & Total & & $\mathbf{1 9 9}$ & $\mathbf{1 9 9}$ \\
\hline
\end{tabular}

Table shows number of acquirer ultimate parents and targets ultimate parents per country in our crossborder M\&A sample to investigate Hypothesis 2. In this context, cross-border M\&As are defined as acquirer ultimate parent and target ultimate parent residing in different countries; the direct acquirer and acquirer ultimate parent reside in the same country and also the direct target and target ultimate parent reside in the same country. CFC rule takes the value one, if the country has implemented CFC rules in 2014. Each country has at least one acquiring firm and one target firm to ensure that maximum likelihood estimation yields finite likelihood. 
Table 15. Definition, data sources and summary statistics of variables for analyzing effect of CFC rules on direction of cross-border M\&As (Section 4.4).

\begin{tabular}{|c|c|c|c|c|c|c|c|}
\hline Variable & Definition & Data source & Obs. & Mean & Std. Dev. & Min & Max \\
\hline$\triangle C F C \_$value & Difference in CFC value of the two firms (see Section 4.2) & Tax guides & 1,199 & 0.059 & 1.536 & -3 & 3 \\
\hline$\triangle C F C \_d u m m y$ & Difference in CFC rule of the two firms (see Section 4.2) & Tax guides & 1,580 & -0.069 & 0.466 & -1 & 1 \\
\hline$\triangle S T R$ & Difference in STRs, including typical local taxes, of the two firms (in \%) & Tax guides & 1,199 & 1.149 & 9.233 & -26.706 & 26.823 \\
\hline$\triangle D T M$ & $\begin{array}{l}\text { Difference in method to avoid double taxation on foreign dividends of two firms } \\
\text { where } 0 \text { (1) represents the credit (exemption) method }\end{array}$ & Tax guides & 1,199 & -0.008 & 0.690 & -1 & 1 \\
\hline$\Delta$ Size & $\begin{array}{l}\text { Difference in total assets of the two firms divided by the sum of the firms' total } \\
\text { assets }\end{array}$ & $\begin{array}{l}\text { SDC; Compustat } \\
\text { North America; } \\
\text { Compustat Global }\end{array}$ & 1,199 & 0.799 & 0.301 & -0.990 & 1.000 \\
\hline$\triangle P T I$ & $\begin{array}{l}\text { Difference in pre-tax incomes of the two firms divided by the sum of the firms' pre- } \\
\text { tax incomes, where non-positive values of pre-tax income are replaced by } 0.001 \text { to } \\
\text { avoid low values in the denominator }\end{array}$ & $\mathrm{SDC}$ & 1,199 & 0.645 & 0.550 & -1.000 & 1.000 \\
\hline$\Delta$ Leverage & Difference in leverage ratios of the two firms (total liabilities/total assets, in \%) & $\begin{array}{l}\text { SDC; Compustat } \\
\text { North America; } \\
\text { Compustat Global }\end{array}$ & 1,199 & -0.082 & 0.942 & -22.413 & 4.314 \\
\hline$\Delta$ StockMrk & $\begin{array}{l}\text { Difference in stock market capitalizations of the two countries divided by the sum } \\
\text { of the countries' stock market capitalization volume }\end{array}$ & World Bank & 1,199 & 0.104 & 0.783 & -1.000 & 1.000 \\
\hline$\Delta$ CreditMrk & $\begin{array}{l}\text { Difference in domestic credits to private sector of the two countries divided by the } \\
\text { sum of the countries' domestic credit volume }\end{array}$ & World Bank & 1,199 & 0.089 & 0.732 & -0.997 & 0.998 \\
\hline Inflation & Difference in inflation rates of the two countries (in \%) & World Bank & 1,199 & 0.037 & 2.106 & -13.352 & 11.742 \\
\hline
\end{tabular}

Data on country fixed effects are not reported but are available upon request. These statistics show relative values of the variables when firm $a$ acquires firm $b$, see expression (11). For example, if firm $a$ has a leverage ratio of 0.45 and firm $b$ has a leverage ratio of 0.50 , then $\Delta$ Leverage takes the value $-0.05(=0.45-0.50)$. 
Table 16. Effect of CFC rules on direction of cross-border M\&As (Section 4.4).

\begin{tabular}{|c|c|c|c|c|c|c|}
\hline \multirow[t]{2}{*}{ Explanatory variables } & \multicolumn{2}{|c|}{$\begin{array}{c}\text { Level of } \\
\text { direct acquirer } \\
\text { \& direct target }\end{array}$} & \multicolumn{4}{|c|}{ Level of acquirer ult. par. \& target ult. par. } \\
\hline & (1) & (2) & (3) & (4) & (5) & (6) \\
\hline$\triangle C F C_{\text {_lvalue }}$ & $\begin{array}{c}-1.127 * * \\
(0.530)\end{array}$ & & $\begin{array}{c}-1.438^{* *} \\
(0.701)\end{array}$ & & $\begin{array}{l}-2.025^{\mathrm{a}} \\
(1.558)\end{array}$ & \\
\hline$\triangle C F C \_d u m m y$ & & $\begin{array}{l}-2.027^{*} \\
(1.132)\end{array}$ & & $\begin{array}{c}-3.543 * * \\
(1.754)\end{array}$ & & $\begin{array}{c}-10.944 * * * \\
(2.620)\end{array}$ \\
\hline$\triangle S T R$ & $\begin{array}{l}0.168^{*} \\
(0.086)\end{array}$ & $\begin{array}{c}0.096^{* *} \\
(0.038)\end{array}$ & $\begin{array}{c}0.278 * * * \\
(0.105)\end{array}$ & $\begin{array}{c}0.062 \\
(0.043)\end{array}$ & $\begin{array}{c}0.693 * * * \\
(0.254)\end{array}$ & $\begin{array}{c}0.079 \\
(0.058)\end{array}$ \\
\hline$\triangle D T M$ & $\begin{array}{l}-0.242 \\
(0.652)\end{array}$ & $\begin{array}{c}0.201 \\
(0.671)\end{array}$ & $\begin{array}{l}-0.910 \\
(0.853)\end{array}$ & $\begin{array}{l}-0.399 \\
(0.879)\end{array}$ & $\begin{array}{c}-1.833 * * \\
(0.927)\end{array}$ & $\begin{array}{l}-0.881 \\
(1.040)\end{array}$ \\
\hline$\Delta$ Size & $\begin{array}{c}5.101 * * * \\
(0.398)\end{array}$ & $\begin{array}{c}5.509 * * * \\
(0.409)\end{array}$ & $\begin{array}{c}5.480 * * * \\
(0.501)\end{array}$ & $\begin{array}{c}5.698 * * * \\
(0.477)\end{array}$ & $\begin{array}{c}7.523 * * * \\
(1.403)\end{array}$ & $\begin{array}{c}6.037 * * * \\
(0.886)\end{array}$ \\
\hline$\triangle P T I$ & $\begin{array}{c}1.177 * * * \\
(0.407)\end{array}$ & $\begin{array}{c}1.128 * * * \\
(0.375)\end{array}$ & $\begin{array}{c}1.399 * * * \\
(0.466)\end{array}$ & $\begin{array}{c}1.307 * * * \\
(0.366)\end{array}$ & $\begin{array}{c}1.571 \\
(1.040)\end{array}$ & $\begin{array}{c}0.906 \\
(0.844)\end{array}$ \\
\hline$\Delta$ Leverage & $\begin{array}{c}0.158^{* * *} \\
(0.068)\end{array}$ & $\begin{array}{c}0.216^{* *} \\
(0.086)\end{array}$ & $\begin{array}{l}0.123 * \\
(0.068)\end{array}$ & $\begin{array}{c}0.206 * * \\
(0.083)\end{array}$ & $\begin{array}{l}-0.098 \\
(0.983)\end{array}$ & $\begin{array}{l}-0.372 \\
(0.638)\end{array}$ \\
\hline$\Delta$ StockMrk & $\begin{array}{c}4.914 * * * \\
(1.615)\end{array}$ & $\begin{array}{c}2.802 * * \\
(1.292)\end{array}$ & $\begin{array}{c}6.446^{* * *} \\
(2.278)\end{array}$ & $\begin{array}{l}3.004^{* *} \\
(1.459)\end{array}$ & $\begin{array}{c}9.175^{* * *} \\
(3.105)\end{array}$ & $\begin{array}{c}2.896 \\
(2.410)\end{array}$ \\
\hline$\Delta$ CreditMrk & $\begin{array}{c}-6.363 * * * \\
(1.848)\end{array}$ & $\begin{array}{l}-2.533^{*} \\
(1.403)\end{array}$ & $\begin{array}{c}-8.826 * * * \\
(2.851)\end{array}$ & $\begin{array}{l}-3.069 \\
(1.884)\end{array}$ & $\begin{array}{l}-9.829^{*} \\
(5.900)\end{array}$ & $\begin{array}{c}0.013 \\
(4.130)\end{array}$ \\
\hline$\Delta$ Inflation & $\begin{array}{c}0.193 \\
(0.205)\end{array}$ & $\begin{array}{c}0.083 \\
(0.171)\end{array}$ & $\begin{array}{c}0.321 \\
(0.245)\end{array}$ & $\begin{array}{c}0.132 \\
(0.210)\end{array}$ & $\begin{array}{c}0.245 \\
(0.534)\end{array}$ & $\begin{array}{c}0.002 \\
(0.427)\end{array}$ \\
\hline Country fixed effects & YES & YES & YES & YES & YES & YES \\
\hline Observations & 1,199 & 1,580 & 989 & 1,305 & 418 & 492 \\
\hline Number & 30 & 31 & 30 & 30 & 29 & 29 \\
\hline Log-likelihood & -99.2 & -133.6 & -70.2 & -100.7 & -24.8 & -38.1 \\
\hline Time period & 2002-2014 & $1995-2014$ & 2002-2014 & 1995-2014 & 2002-2014 & 1995-2014 \\
\hline
\end{tabular}

Logit regressions of probability of being the acquirer country on (potential) CFC rules in a cross-border M\&A; see expression (11). For variable definitions and data sources, see Table 15. All regressions control for country fixed effects, which are available upon request. Regressions (1) and (2) consider M\&As where the direct acquirer and direct target reside in the same country as their respective ultimate parents. Regressions (3) and (4) are the same as (1) and (2), but require that the direct acquirer and the direct target are the respective groups' ultimate parents. Regressions (5) and (6) are the same as (3) and (4), but exclude M\&As involving the United States. Regressions (2), (4) and (6) consider in addition years 1995-2001; due to a lack of more detailed historic CFC rule data $\triangle C F C_{-}$value cannot be constructed for the time period 1995-2001. *,**, and *** denote statistical significance at $10 \%, 5 \%$, and $1 \%$ levels, respectively. Robust standard errors are provided in parentheses.

${ }^{a}$ The level of statistical significance is $19.4 \%$. 


\section{References}

Altshuler, R., and H. Grubert. 2006. Governments and multinational corporations in the race to the bottom. Tax Notes International 41: 459-474.

Altshuler, R., and G. Hubbard. 2003. The effect of the tax reform act of 1986 on the location of assets in financial services firms. Journal of Public Economics 87: 109-127.

Arulampalam, W., M. Devereux, and F. Liberini. 2017. Taxes and the location of targets. Working Paper.

Ayers, B., C. Levanowicz, and J. Robinson. 2003. Shareholder taxes in acquisition premiums: The effect of capital gain taxation. The Journal of Finance 58: 2783-2801.

Ayers, B., C. Levanowicz, and J. Robinson. 2007. Capital gains taxes and acquisition activity: Evidence on the lock-in effect. Contemporary Accounting Research 24: 315-344.

Becker, J., and C. Fuest. 2010. Taxing foreign profits with international mergers and acquisitions. International Economic Review 51: 171-186.

Becker, J., and N. Riedel. 2012. Cross-border tax effects on affiliate investment - Evidence from European multinationals. European Economic Review 56: 436-450.

Compustat Global. Standard and Poor's Compustat Global Database.

Compustat North America. Standard and Poor's Compustat North America Database.

Deloitte. 2015. Guide to Controlled Foreign Company Regimes. https://www2.deloitte.com/al/en/pages/tax/articles/guide-to-controlled-foreign-companyregimes.html, retrieved: 02.01.2017.

Desai, M., and J. Hines. 2002. Expectations and expatriations: Tracing the causes and consequences of corporate inversions. National Tax Journal 55: 409-440.

Dharmapala, D., and N. Riedel. 2013. Earnings shocks and tax-motivated income-shifting: Evidence from European multinationals. Journal of Public Economics 97: 95-107.

di Giovanni, J. 2005. What drives capital flows? The case of cross-border M\&A activity and financial deepening. Journal of International Economics 65: 127-149.

Edwards, A., T. Kravet, and R. Wilson. 2016. Trapped cash and the profitability of foreign acquisitions. Contemporary Accounting Research 33: 44-77.

Egger, P., and G. Wamser. 2015. The impact of controlled foreign company legislation on real investments abroad: A multi-dimensional regression discontinuity design. Journal of Public Economics 129: 77-91.

Ernst \& Young. 2004-2016. Worldwide Corporate Tax Guides. http://www.ey.com/gl/en/services/tax/global-tax-guide-archive, retrieved: 02.01.2017.

European Council. 2016. Laying Down Rules Against Tax Avoidance Practices that Directly Affect the Functioning of the Internal Market (Council Directive (EU) 2016/1164 of 12 July 2016). http://eur-lex.europa.eu/legalcontent/EN/TXT/PDF/?uri=CELEX:32016L1164\&from=EN, retrieved: 25.04.2017.

Feld, L., and J. Heckemeyer. 2011. FDI and taxation: A meta-study. Journal of Economic Surveys 25: 233-272.

Feld, L., M. Ruf, U. Scheuering, U. Schreiber, and J. Voget. 2016a. Repatriation taxes and outbound M\&As. Journal of Public Economics 139: 13-27.

Feld, L., M. Ruf, U. Schreiber, M. Todtenhaupt, and J. Voget. 2016b. Taxing away M\&A: The effect of corporate capital gains taxes on acquisition activity. Working Paper.

Grubert, H. 2012. Foreign taxes and the growing share of U.S. multinational company income abroad: Profits, not sales, are being globalized. National Tax Journal 65: 247-282. 
Hanlon, M., R. Lester, and R. Verdi. 2015. The effect of repatriation tax costs on U.S. multinational investment. Journal of Financial Economics 116: 179-196.

Head, K., T. Mayer, and J. Ries. 2010. The erosion of colonial trade linkages after independence. Journal of International Economics 81: 1-14.

Hebous, S., M. Ruf, and A. Weichenrieder. 2011. The effects of taxation on the location decision of multinational firm: M\&A versus greenfield investment. National Tax Journal 64: 817-838.

Helpman, E., M. Melitz, and S. Yeaple. 2004. Export versus FDI with heterogenous firms. American Economic Review 94: 300-316.

Herger, N., C. Kotsogiannis, and S. McCorriston. 2016. Multiple taxes and alternative forms of FDI: Evidence from cross-border acquisitions. International Tax and Public Finance 23: 82-113.

Huizinga, H., and L. Laeven. 2008. International profit shifting within multinationals: A multi-country perspective. Journal of Public Economics 92: 1164-1182.

Huizinga, H., and J. Voget. 2009. International taxation and the direction and volume of cross-border M\&As. The Journal of Finance 64: 1217-1249.

Huizinga, H., J. Voget, and W. Wagner. 2012. Who bears the burden of international taxation? Evidence from cross-border M\&As. Journal of International Economics 88: 186-197.

Huizinga, H., J. Voget, and W. Wagner. 2017. Capital gains taxation and the cost of capital: Evidence from unanticipated cross-border transfers of tax bases. Journal of Financial Economics forthcoming.

IBFD European Tax Handbook. 2002-2016. European Tax Handbook, Amsterdam (Netherlands): International Bureau of Fiscal Documentation.

KPMG. 2016. Corporate tax rates table. https://home.kpmg.com/xx/en/home/services/tax/taxtools-and-resources/tax-rates-online/corporate-tax-rates-table.html, retrieved: 02.01.2017.

Lewellen, K., and L. Robinson. 2014. Internal ownership structures of U.S. multinational firms. Working Paper.

Mayer, T., and S. Zignago. 2011. Notes on CEPII's distance measures: The GeoDist database. Working Paper.

Melitz, J., and F. Toubal. 2014. Native language, spoken language, translation and trade. Journal of International Economics 93: 351-363.

Mitchell, M., and H. Mulherin. 1996. The impact of industry shocks on takeover and restructuring activity. Journal of Financial Economics 41: 193-229.

Mutti, J., and H. Grubert. 2009. The effect of taxes on royalties and the migration of intangible assets abroad. International Trade in Services and Intangibles in the Era of Globalization: 111-137.

OECD/G20. 2015. Base Erosion and Profit Shifting Project - Explanatory Statement. http://dx.doi.org/10.1787/9789264263437-en, retrieved: 02.01.2017.

Oxford University Centre for Business Taxation. CBT Tax Database (Data Set). https://www.sbs.ox.ac.uk/faculty-research/tax/publications/data, retrieved: 02.01.2017.

Ruf, M., and A. Weichenrieder. 2012. The taxation of passive foreign investment: Lessons from German experience. Canadian Journal of Economics 45: 1504-1528.

Ruf, M., and A. Weichenrieder. 2013. CFC legislation, passive assets and the impact of the ECJ's Cadbury-Schweppes decision. Working Paper.

SDC. Thomson Financial SDC Database. 
UNCTAD. 2017. World Investment Report - Investment and the Digital Economy, Geneva (Switzerland): United Nations Publications.

Voget, J. 2011. Relocation of headquarters and international taxation. Journal of Public Economics 95: 1067-1081.

Weichenrieder, A. 1996. Anti-tax-avoidance provisions and the size of foreign direct investment. International Tax and Public Finance 3: 67-81.

Weichenrieder, A. 2009. Profit shifting in the EU: Evidence from Germany. International Tax and Public Finance 16: 281-297.

World Bank. World Bank Open Data (Data Set). http://data.worldbank.org, retrieved: 02.01.2017. 


\section{Oxford University Centre for Business Taxation Working Paper series recent papers}

WP17/16 Marie Lamensch Destination based taxation of corporate profits - preliminary findings regarding tax collection in cross-border situations

WP17/15 Li Liu Tim Schmidt-Eisenlohr and Dongxian Guo International transfer pricing and tax avoidance: Evidence from linked trade-tax statistics in the UK.

WP17/14 Katarzyna Habu How much tax do companies pay in the UK?

WP17/13 Katarzyna Habu How aggressive are foreign multinational companies in reducing their corporation tax liability?

WP17/12 Edward D. Kleinbard The right tax at the right time

WP17/11 Aaron Flaaen The role of transfer prices in profit-shifting by U.S. multinational firms: Evidence from the 2004 Homeland Investment Act

WP17/10 Ruud de Mooij and Li Liu At a cost: The real effect of transfer pricing regulations on multinational investments

WP17/09 Wei Cui Taxation without information: The institutional foundations of modern tax collection

WP17/08 John Brooks The definitions of income

WP17/07 Michael P. Devereux and John Vella Implications of Digitalization for International Corporation Tax Reform

WP17/06 Richard Collier and Michael P. Devereux The Destination-Based Cash Flow Tax and the Double Tax Treaties

WP17/05 Li Liu Where does multinational investment go with Territorial Taxation

WP17/04 Wiji Arulampalam, Michael P Devereux and Federica Liberini Taxes and Location of Targets

WP17/03 Johannes Becker and Joachim Englisch A European Perspective on the US plans for a Destination based cash flow tax

WP17/02 Andreas Haufler, Mohammed Mardan and Dirk Schindler Double tax discrimination to attract FDI and fight profit shifting: The role of CFC rules

WP17/01 Alan Auerbach, Michael P. Devereux, Michael Keen and John Vella Destinationbased cash flow taxation

WP16/14 Anzhela Cédelle The EU Anti-Tax Avoidance Directive: A UK Perspective 
WP16/13 Michael Devereux Measuring corporation tax uncertainty across countries: Evidence from a cross-country survey

WP16/12 Andreas Haufler and Ulf Maier Regulatory competition in capital standards with selection effects among banks

WP16/11 Katarzyna Habu Are financing constraints binding for investment? Evidence from natural experiment

WP 16/10 Li Liu and Ben Lockwood VAT notches, voluntary registration and bunching: Theory and UK evidence

WP 16/09 Harry Grubert and Roseanne Altshuler Shifting the burden of taxation from the corporate to the personal level and getting the corporate tax rate down to 15 percent

WP 16/08 Margaret K McKeehan and George R Zodrow Balancing act: weighing the factors affecting the taxation of capital income in a small open economy

WP 16/07 Michael P Devereux and Li Liu Stimulating investment through incorporation WP16/05 Tobias Böhm, Nadine Riedel and Martin Simmler Large and influential: firm size and governments' corporate tax rate choice?

WP16/04 Dhammika Dharmapala The economics of corporate and business tax reform

WP 16/03 Rita de la Feria EU VAT principles as interpretative aids to EU VAT rules: the inherent paradox

WP 16/02 Irem Guceri Will the real R\&D employees please stand up? Effects of tax breaks on firm level outcomes

WP 16/01 Giorgia Maffini, Jing Xing and Michael P Devereux The impact of investment incentives: evidence from UK corporation tax returns

WP 15/33 Anzhela Cédelle Enhanced co-operation: a way forward for tax harmonisation in the EU?

WP 15/32 James Mahon and Eric Zwick Do experts help firms optimise?

WP 15/31 Robin Boadway, Motohiro Sato and Jean-François Tremblay Cash-flow business taxation revisited: bankruptcy, risk aversion and asymmetric information

WP 15/30 Martin Simmler Do multinational firms invest more? On the impact of internal debt financing and transfer pricing on capital accumulation

WP 15/29 Daniel Shaviro The crossroads versus the seesaw: getting a 'fix' on recent international tax policy developments 
WP 15/28 Zhonglan Dai, Douglas A Shackelford, Yue (Layla) Ying and Harold H Zhang Do companies invest more after shareholder tax cuts?

WP 15/27 Martin Ruf and Julia Schmider Who bears the cost of taxing the rich? An empirical study on CEO pay

WP 15/26 Eric Orhn The corporate investment response to the domestic production activities deduction

WP 15/25 Li Liu International taxation and MNE investment: evidence from the UK change to territoriality

WP 15/24 Edward D Kleinbard Reimagining capital income taxation

WP 15/23 James R Hines Jr, Niklas Potrafke, Marina Riem and Christoph Schinke Inter vivos transfers of ownership in family firms

WP 15/22 Céline Azémar and Dhammika Dharmapala Tax sparing agreements, territorial tax reforms, and foreign direct investment

WP 15/21 Wei Cui A critical review of proposals for destination-based cash-flow corporate taxation as an international tax reform option

WP 15/20 Andrew Bird and Stephen A Karolyi Governance and taxes: evidence from regression discontinuity

WP 15/19 Reuven Avi-Yonah Reinventing the wheel: what we can learn from the Tax Reform Act of 1986

WP 15/18 Annette Alstadsæter, Salvador Barrios, Gaetan Nicodeme, Agnieszka Maria Skonieczna and Antonio Vezzani Patent boxes design, patents, location and local R\&D

WP 15/17 Laurent Bach Do better entrepreneurs avoid more taxes?

WP 15/16 Nadja Dwenger, Frank M Fossen and Martin Simmler From financial to real economic crisis: evidence from individual firm-bank relationships in Germany

WP 15/15 Giorgia Maffini and John Vella Evidence-based policy-making? The Commission's proposal for an FTT

WP 15/14 Clemens Fuest and Jing Xing How can a country 'graduate' from procyclical fiscal policy? Evidence from China?

WP 15/13 Richard Collier and Giorgia Maffini The UK international tax agenda for business and the impact of the OECD BEPS project

WP 15/12 Irem Guceri and Li Liu Effectiveness of fiscal incentives for R\&D: quasiexperimental evidence 
WP 15/11 Irem Guceri Tax incentives and R\&D: an evaluation of the 2002 UK reform using micro data

WP 15/10 Rita de la Feria and Parintira Tanawong Surcharges and penalties in UK tax law

WP 15/09 Ernesto Crivelli, Ruud de Mooij, Michael Keen Base erosion, profit-shifting and developing countries

WP 15/08 Judith Freedman Managing tax complexity: the institutional framework for tax policy-making and oversight

WP 15/07 Michael P Devereux, Giorgia Maffini and Jing Xing Corporate tax incentives and capital structure: empirical evidence from UK tax returns

WP 15/06 Li Liu and Ben Lockwood VAT notches

WP 15/05 Clemens Fuest and Li Liu Does ownership affect the impact of taxes on firm behaviour? Evidence from China.

WP 15/04 Michael P Devereux, Clemens Fuest and Ben Lockwood The taxation of foreign profits: a unified view

WP 15/03 Jitao Tang and Rosanne Altshuler The spillover effects of outward foreign direct investment on home countries: evidence from the United States

WP 15/02 Juan Carlos Suarez Serrato and Owen Zidar Who benefits from state corporate tax cuts? A local labour markets approach with heterogeneous firms

WP 15/01 Ronald B Davies, Julien Martin, Mathieu Parenti and Farid Toubal Knocking on Tax Haven's Door: multinational firms and transfer pricing

WP14/29 Anzhela Yevgenyeva The taxation of non-profit organizations after Stauffer

WP 14/28 Peter Birch Sørensen Taxation of shareholder income and the cost of capital in a small open economy

WP 14/27 Peter Birch Sørensen Taxation and the optimal constraint on corporate debt finance

WP 14/26 Johannes Becker, Ronald B Davies and Gitte Jakobs The economics of advance pricing agreements

WP 14/25 Michael P Devereux and John Vella Are we heading towards a corporate tax system fit for the 21 st century?

WP 14/24 Martin Simmler Do multinational firms invest more? On the impact of internal debt financing on capital accumulation

WP 14/23 Ben Lockwood and Erez Yerushalmi Should transactions services be taxed at the same rate as consumption? 
WP 14/22 Chris Sanchirico As American as Apple Inc: International tax and ownership nationality

WP 14/19 Jörg Paetzold and Hannes Winner Taking the High Road? Compliance with commuter tax allowances and the role of evasion spillovers

WP 14/18 David Gamage How should governments promote distributive justice?: A framework for analyzing the optimal choice of tax instruments

WP 14/16 Scott D Dyreng, Jeffrey L Hoopes and Jaron H Wilde Public pressure and corporate tax behaviour

WP 14/15 Eric Zwick and James Mahon Do financial frictions amplify fiscal policy? Evidence from business investment stimulus

WP 14/14 David Weisbach The use of neutralities in international tax policy

WP 14/13 Rita de la Feria Blueprint for reform of VAT rates in Europe

WP 14/12 Miguel Almunia and David Lopez Rodriguez Heterogeneous responses to effective tax enforcement: evidence from Spanish firms

WP 14/11 Charles E McLure, Jack Mintz and George R Zodrow US Supreme Court unanimously chooses substance over form in foreign tax credit

WP 14/10 David Neumark and Helen Simpson Place-based policies

WP 14/09 Johannes Becker and Ronald B Davies A negotiation-based model of taxinduced transfer pricing

WP 14/08 Marko Koethenbuerger and Michael Stimmelmayr Taxing multinationals in the presence of internal capital markets

WP 14/07 Michael Devereux and Rita de la Feria Designing and implementing a destination-based corporate tax

WP 14/05 John W Diamond and George R Zodrow The dynamic economic effects of a US corporate income tax rate reduction

WP 14/04 Claudia Keser, Gerrit Kimpel and Andreas Oesterricher The CCCTB option - an experimental study

WP 14/03 Arjan Lejour The foreign investment effects of tax treaties

WP 14/02 Ralph-C. Bayer Harald Oberhofer and Hannes Winner The occurrence of tax amnesties: theory and evidence 
WP14/01 Nils Herger, Steve McCorriston and Christos Kotsogiannisz Multiple taxes and alternative forms of FDI: evidence from cross-border acquisitions 